\title{
Article \\ Silicon Dioxide Nanoparticles Induce Innate Immune Responses and Activate Antioxidant Machinery in Wheat Against Rhizoctonia solani
}

\author{
Abdelrazek S. Abdelrhim 1(D), Yasser S. A. Mazrou 2,3, Yasser Nehela 4,5,*id, Osama O. Atallah ${ }^{6}$ (D), \\ Ranya M. El-Ashmony ${ }^{1}$ and Mona F. A. Dawood ${ }^{7}$ (D) \\ 1 Department of Plant Pathology, Faculty of Agriculture, Minia University, El-Minya 61512, Egypt; \\ Abdelrazek.sharawy@mu.edu.eg (A.S.A.); ranya.elashmoni@mu.edu.eg (R.M.E.-A.) \\ 2 Business Administration Department, Community College, King Khalid University, Guraiger, \\ Abha 62529, Saudi Arabia; ymazrou@kku.edu.sa or yasser.mazroua@agr.tanta.edu.eg \\ 3 Department of Agriculture Economic, Faculty of Agriculture, Tanta University, Tanta 31527, Egypt \\ 4 Department of Agricultural Botany, Faculty of Agriculture, Tanta University, Tanta 31511, Egypt \\ 5 Citrus Research and Education Center, Department of Plant Pathology, University of Florida, \\ 700 Experiment Station Rd., Lake Alfred, FL 33850, USA \\ 6 Department of Plant Pathology, Zagazig University, Zagazig 44519, Egypt; osamaoatall1h@ufl.edu \\ 7 Botany and Microbiology Department, Faculty of Science, Assiut University, Assiut 71516, Egypt; \\ mo_fa87@aun.edu.eg \\ check for \\ * Correspondence: yasser.nehela@ufl.edu
}

updates

Citation: Abdelrhim, A.S.; Mazrou, Y.S.A.; Nehela, Y.; Atallah, O.O.; El-Ashmony, R.M.; Dawood, M.F.A. Silicon Dioxide Nanoparticles Induce Innate Immune Responses and Activate Antioxidant Machinery in Wheat Against Rhizoctonia solani. Plants 2021, 10, 2758. https:// doi.org/10.3390/plants10122758

Academic Editors: Sylwia Magdalena Okoń, Krzysztof Kowalczyk, Tomasz Ociepa, Vittorio Rossi and Rene Kizek

Received: 30 October 2021

Accepted: 11 December 2021

Published: 14 December 2021

Publisher's Note: MDPI stays neutral with regard to jurisdictional claims in published maps and institutional affiliations.

Copyright: (c) 2021 by the authors. Licensee MDPI, Basel, Switzerland. This article is an open access article distributed under the terms and conditions of the Creative Commons Attribution (CC BY) license (https:/ / creativecommons.org/licenses/by/ $4.0 /)$.
Abstract: The phytopathogenic basidiomycetous fungus, Rhizoctonia solani, has a wide range of host plants including members of the family Poaceae, causing damping-off and root rot diseases. In this study, we biosynthesized spherical-shaped silicon dioxide nanoparticles $\left(\mathrm{SiO}_{2} \mathrm{NPs}\right.$; sized between 9.92 and $19.8 \mathrm{~nm}$ ) using saffron extract and introduced them as a potential alternative therapeutic solution to protect wheat seedlings against $R$. solani. $\mathrm{SiO}_{2} \mathrm{NPs}$ showed strong dosedependent fungistatic activity on $R$. solani, and significantly reduced mycelial radial growth (up to $100 \%$ growth reduction), mycelium fresh and dry weight, and pre-, post-emergence damping-off, and root rot severities. Moreover, the impact of $\mathrm{SiO}_{2} \mathrm{NPs}$ on the growth of wheat seedlings and their potential mechanism (s) for disease suppression was deciphered. $\mathrm{SiO}_{2} \mathrm{NPs}$ application also improved the germination, vegetative growth, and vigor indexes of infected wheat seedlings which indicates no phytotoxicity on treated wheat seedlings. Moreover, $\mathrm{SiO}_{2} \mathrm{NPs}$ enhanced the content of the photosynthetic pigments (chlorophylls and carotenoids), induced the accumulation of defenserelated compounds (particularly salicylic acid), and alleviated the oxidative stress via stimulation of both enzymatic (POD, SOD, APX, CAT, and PPO) and non-enzymatic (phenolics and flavonoids) antioxidant defense machinery. Collectively, our findings demonstrated the potential therapeutic role of $\mathrm{SiO}_{2}$ NPs against $R$. solani infection via the simultaneous activation of a multilayered defense system to suppress the pathogen, neutralize the destructive effect of ROS, lipid peroxidation, and methylglyoxal, and maintain their homeostasis within $R$. solani-infected plants.

Keywords: Rhizoctonia solani; wheat; nanoparticles; silicon dioxide; root rot; damping-off; ROS; antioxidant

\section{Introduction}

Wheat (Triticum aestioum L.) is an important cereal crop worldwide, which is considered stable food for about one-third of the world population. Wheat plays an important role in total cereal production and global food security [1]. It comes after rice and corn with respect to stable food for most of the world population. Rhizoctonia spp. is among various fungal pathogens that cause wheat diseases and affect wheat [2,3]. Two anamorph species of genus Rhizoctonia, which causes root disease on wheat and negatively affects its 
yield, are widely recognized and studied. These include Rhizoctonia solani and Rhizoctonia cerealis, which are common pathogens, attacking various crops including wheat [4]. $R$. solani Kühn (teleomorph = Thanatephorus cucumeris Donk) is a plant pathogenic fungus that causes serious damage and yield losses to wheat plants during the growing season.

$R$. solani causes what is called bare patch or purple patch which appeared as localized patchy, stunted areas in the field $[5,6]$. Different countries, such as the Pacific Northwest United States, Australia, Asia, and parts of Europe considered Rhizoctonia root rot as a major problem [7-9]. The yield losses resulting from $R$. solani averaged up to $20 \%$ yearly of wheat crops worldwide [10].

Unfortunately, the inoculum of soilborne pathogens that cause root diseases of grown plants in general and wheat and barley specifically often survives longer in the soil as it remains undisturbed and covered within crop residue [11]. Therefore, various management strategies are required to achieve integrated management against damping-off and root rot causal pathogens. The impact of applying conventional fungicides to control Rhizoctonia species is vague and not considerable $[12,13]$. Thus, finding an effective material, which has fungicidal activity and a positive impact on plant growth is urgent.

Nanotechnology is an important tool of modern science that has contributed to every sector of life. Nanoparticles are particles having a size range between 1 and $100 \mathrm{~nm}[14,15]$ and have physicochemical properties which differ from the bulk materials [16]. Nanoparticles may help to improve nutrients, could be used as growth stimulators and as plant protection products. Many studies have confirmed the ability of nanomaterials to improve seed germination and seedling early growth [17-19]. A positive effect of different nanoparticles, i.e., titanium dioxide, zinc oxide, nickel, and chitosan on the growth of wheat seedlings were reported $[20,21]$. Among all known microelements, silicon (Si) comes after oxygen with respect to its abundance, it is the most important mineral element in the soil, it is also recognized as a beneficial nutrient that enhances seed germination, improves and develops plant growth, which leads to increased crop production $[19,22]$. In addition to plant growth improvement, silicon stimulates the resistance mechanisms of plants against biotic $[23,24]$ and abiotic stress $[18,19]$. Si is known to suppress many plant diseases, such as bacterial blight, brown spot, grain discoloration, leaf scald, leaf and panicle blast, stem rot, and sheath blight in rice, as well as powdery mildew in wheat and cucumber [25]. In wheat, silicon achieved a significant reduction of many fungal diseases, such as powdery mildew caused by Blumeria graminis f. sp. graminis [23,26], Septoria leaf blotch [27], leaf blast caused by Pyricularia oryzae [28], leaf rust caused by Puccinia triticina and yellow spot caused by Drechslera tritici-repentis [24], eyespot caused by Oculimacula yallundae [29], and spot blotch Bipolaris sorokiniana [30]. Therefore, increasing the efficacy of silicon by reducing its particle size to the nano level using a safe synthesizing technique could have a positive influence on its performance in improving plant growth, resistance, and suppressing plant pathogenic fungi.

In this study, we biosynthesized silicon nanoparticles with unique properties using saffron extract, and we tested the impact of those particles at different concentrations on the growth of wheat seedlings and the severity of wheat root rot disease caused by $R$. solani. The effect of $\mathrm{SiO}_{2} \mathrm{NPs}$ on the linear growth of $R$. solani was examined as well. In addition, the effect of $\mathrm{SiO}_{2} \mathrm{NPs}$ on the resistance-related enzymes in wheat seedlings was also evaluated.

\section{Results}

\subsection{Characterization of $\mathrm{SiO}_{2} \mathrm{NPS}$}

The FTIR spectra of $\mathrm{SiO}_{2}$ NPs synthesized using saffron stigmas extract showed different bands at $3405,1634,1103,801$, and $471 \mathrm{~cm}^{-1}$ (Figure 1A), which correspond to $\mathrm{O}-\mathrm{H}$ stretch hydrogen-bonded, $\mathrm{C}=\mathrm{C}$ stretch, $\mathrm{C}-\mathrm{O}$ stretch, and the symmetric vibration of $\mathrm{Si}$ atoms, respectively. The XRD spectrum of $\mathrm{SiO}_{2} \mathrm{NPs}$ expressed broadband with reflection at $2 \theta=22.8^{\circ}$ and no additional peaks were observed by the XRD spectrum (Figure 1B). The presence of $\mathrm{SiO}_{2} \mathrm{NPs}$ was confirmed by exhibiting a peak at approximately $440 \mathrm{~nm}$ in 
UV-Vis spectra (Figure 1C). The nanoparticles size ranged from 9.92 to $19.8 \mathrm{~nm}$ as obtained from TEM images (Figure 1D). Obtained NPs were spherically shaped, which was detected by using TEM. Data from the energy dispersion spectrum (EDS) of Si K $\alpha 1$ (Figure S1A), O $\mathrm{K} \alpha 1$ (Figure $\mathrm{S1B}$ ), and $\mathrm{SiO}_{2}$ (Figure $1 \mathrm{E}$ ) showed that $\mathrm{SiO}_{2} \mathrm{NPs}$ contained almost 2:1 oxygen and silicon, respectively ( $71 \% \mathrm{O}$ and $29 \% \mathrm{Si}$; Figure $1 \mathrm{~F})$.
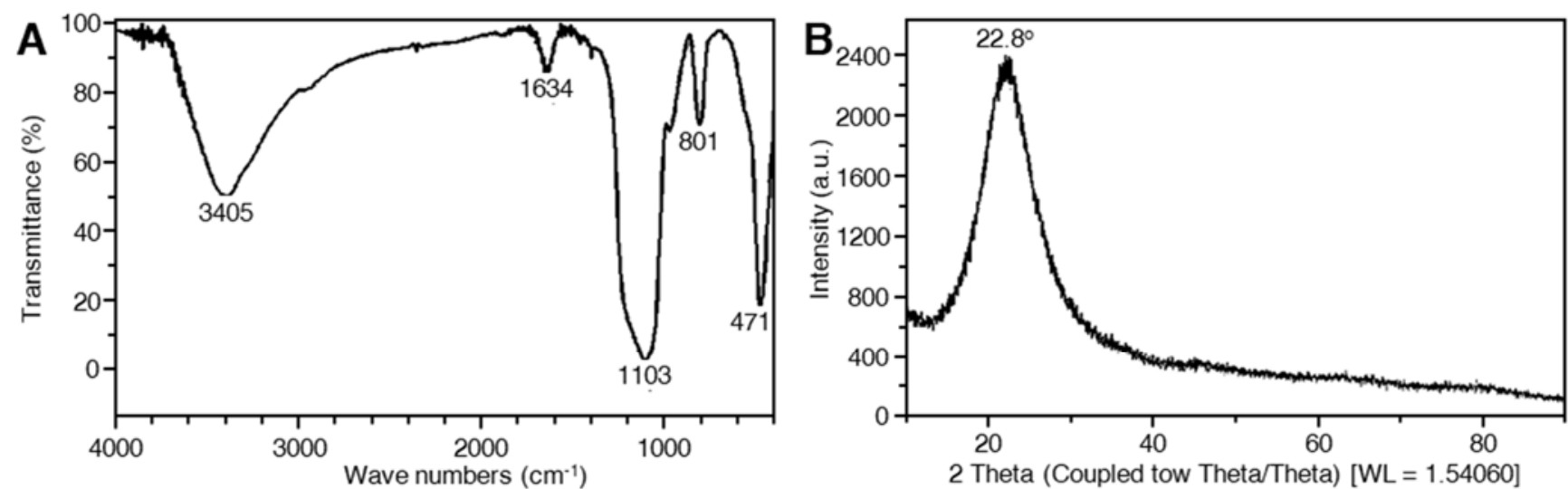

2 Theta (Coupled tow Theta/Theta) [WL $=1.54060]$
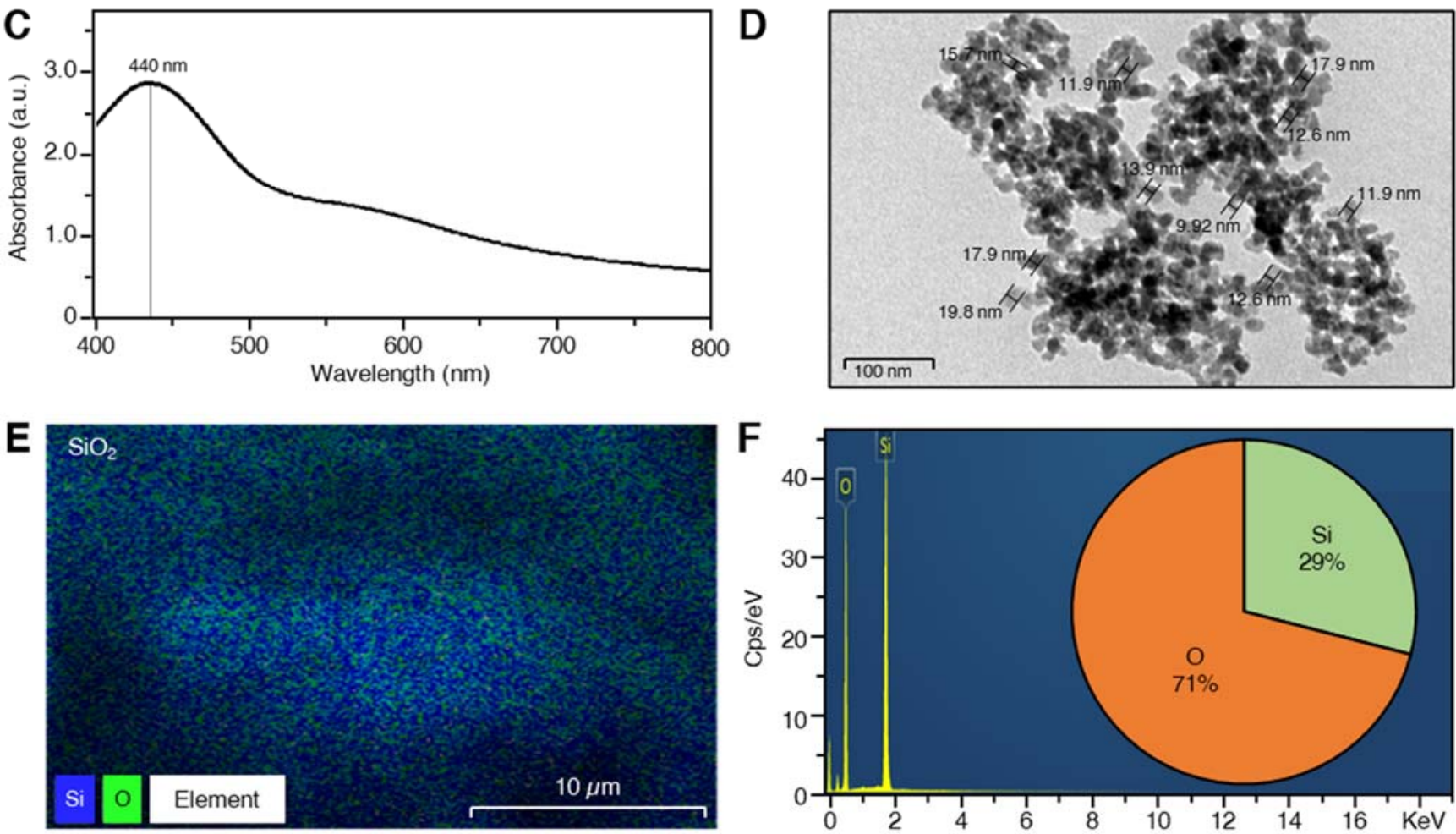

Figure 1. Structural and compositional characterization of silicon dioxide nanoparticles $\left(\mathrm{SiO}_{2} \mathrm{NPs}\right)$. (A) FTIR spectrum, (B) X-ray diffraction patterns, (C) UV-Vis spectrum, (D) Bright-field TEM image, (E) energy-dispersive X-ray spectroscopy (EDS) elemental mapping of $\mathrm{SiO}_{2}$, and (F) Energy dispersion spectrum (EDS) and its associated percentage of each element.

\subsection{Responses of Wheat Cultivars to R. solani}

The tested wheat cultivars showed variable responses to $R$. solani infection (Figure 2). The tested isolate expressed symptoms of pre-, post-emergence damping-off and root rot on all wheat cultivars. The highest pre-emergence damping-off values were observed on wheat cvs. Giza-171 (30\%), Giza-168 and Misr-1 (28\%). However, a low percentage of pre-emergence damping-off was observed on Sids-13 (15\%). The percentages of postemergence damping-off varied from 33 to $40 \%$. Giza-168, Giza-171, and Misr-2 were the most susceptible, which showed $40 \%$ post-emergence damping-off, while the lowest post- 
emergence damping-off was noticed on Gemmeiza-11 (30\%). R. solani was also able to cause root rot on all wheat cultivars ranging from 10 to $22 \%$. Giza-168 has exhibited the highest root rot $(22 \%)$, while the lowest root rot $(10 \%)$ was recorded on Gemmeiza-12 (Figure 2). Additionally, wheat cultivars were estimated to have root rot symptoms caused by $R$. solani. Giza-168 was the most susceptible wheat cultivar showing 22\% root rot. Moreover, Giza-171 and Misr-1 showed 19 and 17\% root rot, respectively. However, Gemmeiza-11, Gemmeiza-12, and Sids-14 were the most resistant cultivars as they expressed the lowest percentages of root rot and recorded 11, 10 and 12\%, respectively (Figure 2).

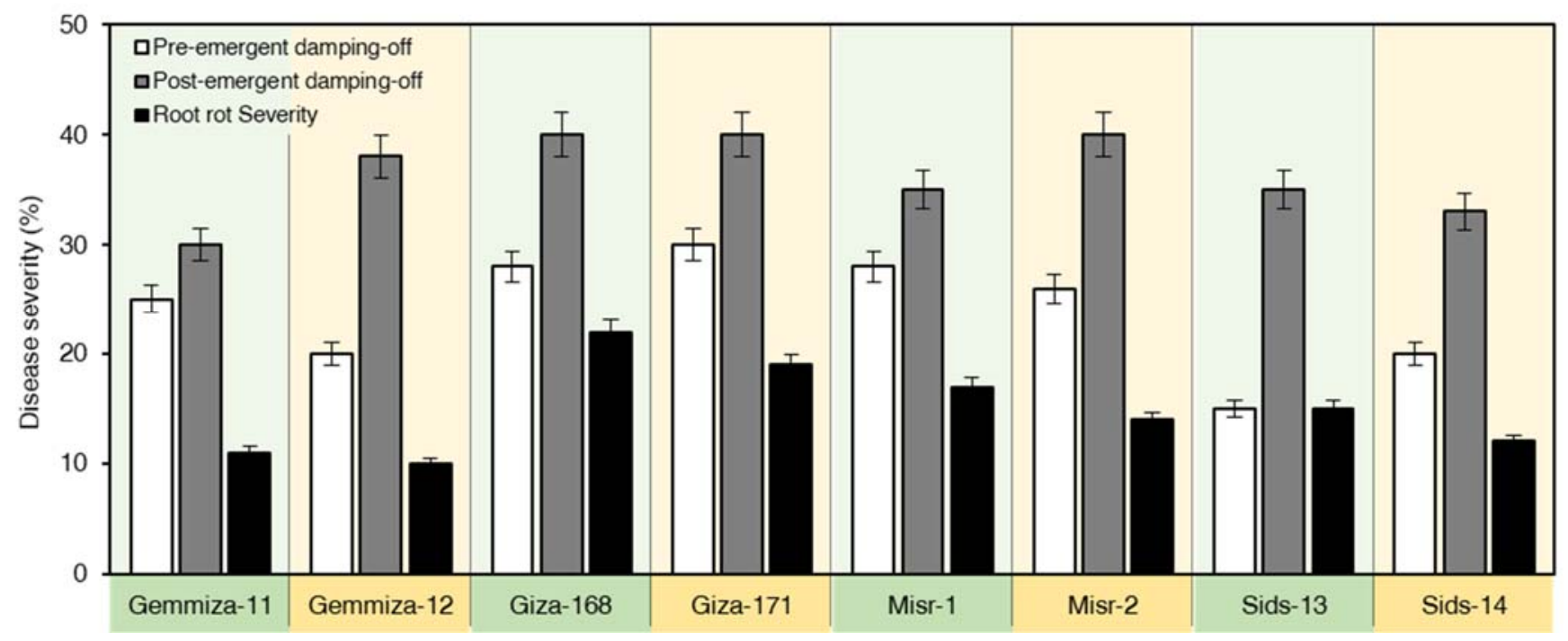

Figure 2. Pathogenicity of $R$. solani against eight Egyptian bread wheat cultivars. The experiment was repeated twice independently. Data presented are means \pm standard deviation (mean $\pm \mathrm{SD}$ ) of five biological replicates.

\subsection{In Vitro Antifungal Activity of $\mathrm{SiO}_{2} \mathrm{NPs}$ on $\mathrm{R}$. solani}

The in vitro antifungal activity of biosynthesized $\mathrm{SiO}_{2}$ NPs was tested using two different methods (Figure 3). $\mathrm{SiO}_{2}$ NPs showed a strong dose-dependent fungistatic activity against $R$. solani since the higher concentrations showed a wider inhibition zone and vice versa (Figure 3A). The highest concentration of $\mathrm{SiO}_{2}\left(100 \mu \mathrm{g} \mathrm{mL} \mathrm{m}^{-1}\right)$ showed no mycelial growth (100\% growth reduction) of $R$. solani (Figure $3 \mathrm{~A}, \mathrm{~B})$. Applying $\mathrm{SiO}_{2} \mathrm{NPs}_{\text {at }}$ the three concentrations $\left(25,50\right.$ and $\left.100 \mu \mathrm{g} \mathrm{mL}^{-1}\right)$ significantly reduced the linear growth of $R$. solani $\left(\mathrm{y}=-0.0762 \mathrm{x}+6.56, \mathrm{R}^{2}=0.7693\right.$; Figure $3 \mathrm{C}$ ). Consequently, the inhibition ( $\%$ ) of the mycelial growth of $R$. solani was dose-dependent. No fungal growth was observed when mycelium was treated with $100 \mu \mathrm{g} \mathrm{mL}^{-1} \mathrm{SiO}_{2}$ (100\% growth reduction). Similarly, $\mathrm{SiO}_{2}$ NPs showed strong in vitro antifungal activity against $R$. solani growing on liquid media (Figure 3D) as expressed by inhibition of both mycelium fresh (Figure 3E) and dry weight (Figure $3 F)$ of treated cultures. The highest concentration of $\mathrm{SiO}_{2} \mathrm{NPs}\left(100 \mu \mathrm{g} \mathrm{mL}{ }^{-1}\right)$ was the most effective concentration in reducing the fresh and dry weight of $R$. solani mycelial growth by 91.0 and 93.5, respectively (Figure 3E and 3F, respectively).

\section{4. $\mathrm{SiO}_{2} \mathrm{NPS}$ Increased the Extracellular Conductivity of Treated Fungal Suspension}

Treating the mycelium of $R$. solani with $\mathrm{SiO}_{2}$ NPs significantly increased levels of extracellular conductivity compared to control. The conductivity was increased progressively by the time of exposure with a greater effect with the highest concentration of $\mathrm{SiO}_{2} \mathrm{NPs}$ $\left(100 \mu \mathrm{g} \mathrm{mL}^{-1}\right)$. However, there was no significant effect between 12 and $24 \mathrm{~h}$ exposure time to the higher concentration of $\mathrm{SiO}_{2}$ on the conductivity of the supernatant (Figure 3G). 
A

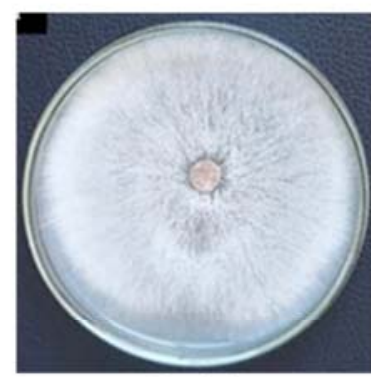

Control

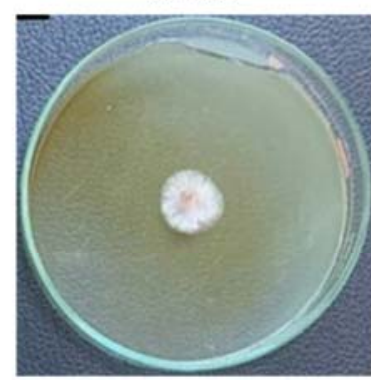

$50 \mu \mathrm{g} \mathrm{SiO}_{2} \mathrm{NPs} \mathrm{mL}^{-1}$
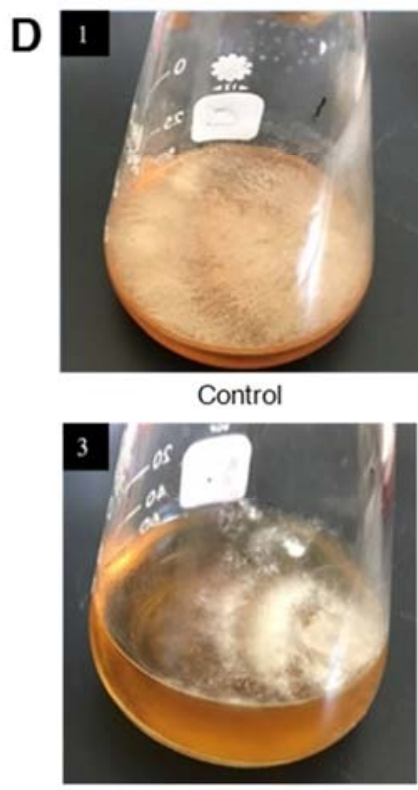

$50 \mu \mathrm{g} \mathrm{SiO}_{2} \mathrm{NPs} \mathrm{mL}^{-1}$

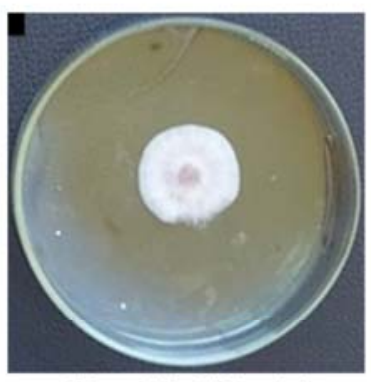

$25 \mu \mathrm{g} \mathrm{SiO}_{2} \mathrm{NPs} \mathrm{mL}^{-1}$

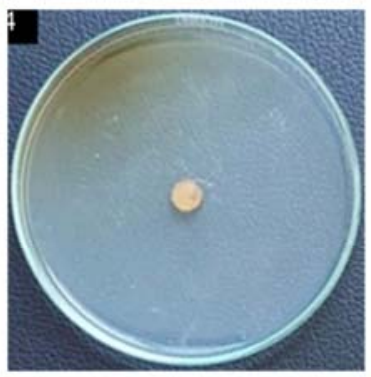

$100 \mu \mathrm{g} \mathrm{SiO}_{2} \mathrm{NPs} \mathrm{mL}^{-1}$

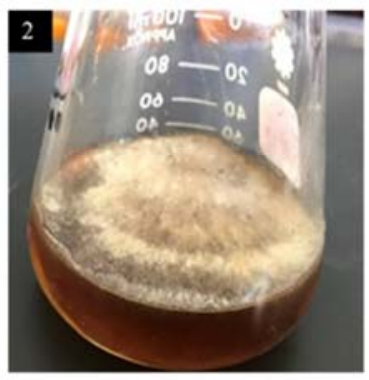

$25 \mu \mathrm{g} \mathrm{SiO}_{2} \mathrm{NPs} \mathrm{mL}^{-1}$

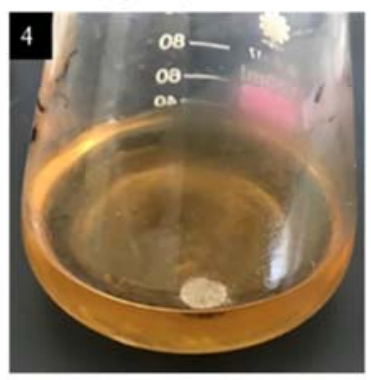

$100 \mu \mathrm{g} \mathrm{SiO}_{2} \mathrm{NPs} \mathrm{mL}^{-1}$
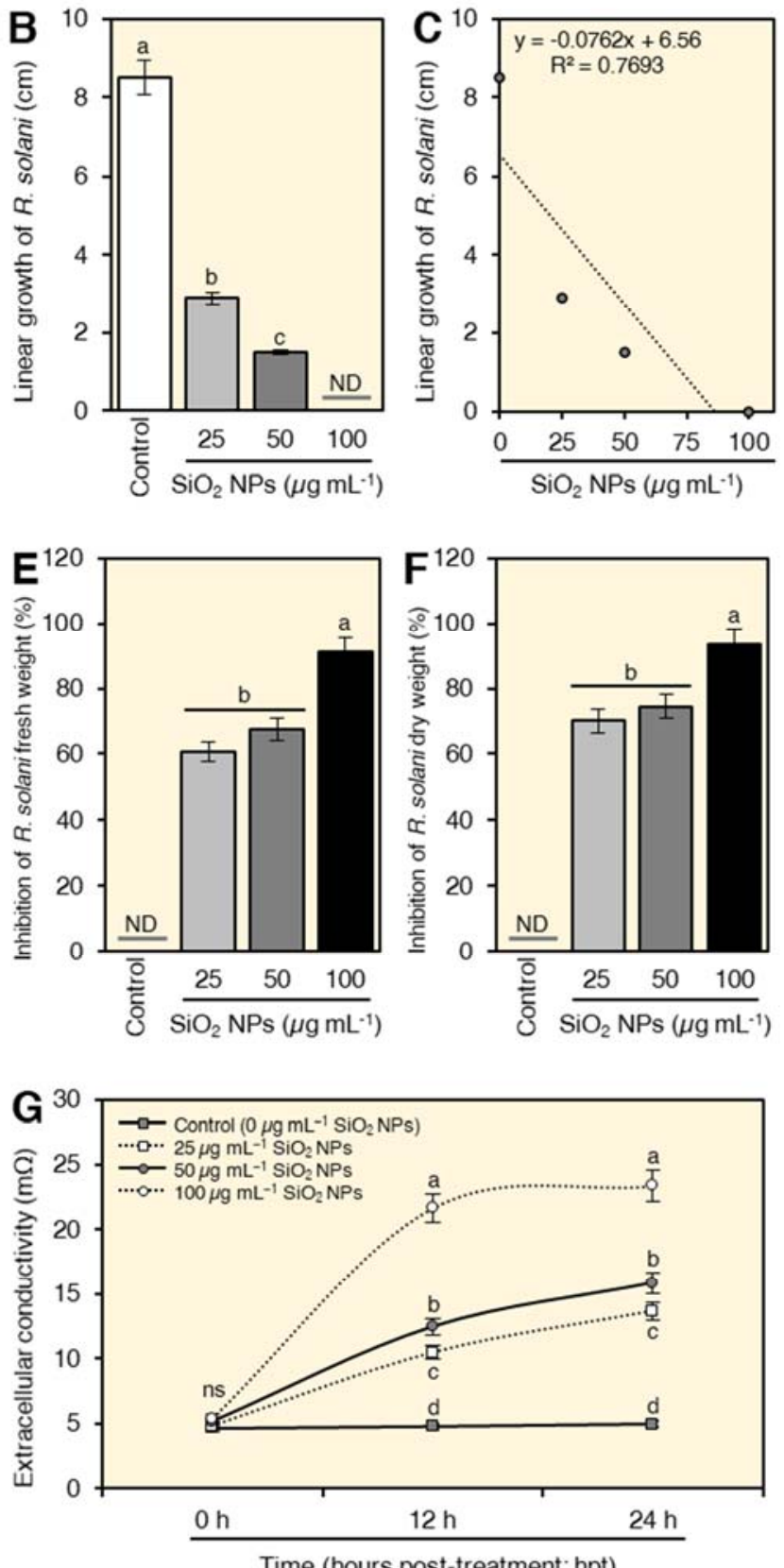

Time (hours post-treatment; hpt)

Figure 3. In vitro antifungal activity of silicon dioxide nanoparticles $\left(\mathrm{SiO}_{2} \mathrm{NPs}\right)$ against $\mathrm{R}$. solani, the causal agent of wheat damping-off. (A) Antifungal activity of different concentrations (0 [control], 25, 50, and $100 \mu \mathrm{g} \mathrm{mL}-1)$ of SiO $2 ~ \mathrm{NPs}^{-1}$ against R. solani growing on PDA medium in Petri dishes. (B) Linear growth $(\mathrm{cm})$ of $R$. solani after the treatment with different concentrations of $\mathrm{SiO}_{2}$ NPs. (C) Simple linear regression between linear growth $(\mathrm{cm})$ of $R$. solani and different concentrations of $\mathrm{SiO}_{2} \mathrm{NPs}\left(0,25,50\right.$, and $\left.100 \mu \mathrm{g} \mathrm{mL}{ }^{-1}\right)$. (D) Antifungal activity of different concentrations (0 [control], 25, 50 , and $100 \mu \mathrm{g} \mathrm{mL}^{-1}$ ) of $\mathrm{SiO}_{2}$ NPs against R. solani growing on liquid medium. (E,F) Inhibition (\%) of $R$. solani fresh and dry weight, respectively, after the treatment with different concentrations of $\mathrm{SiO}_{2} \mathrm{NPs}$. (G) Effect of different concentrations of $\mathrm{SiO}_{2} \mathrm{NPs}$ on the extracellular conductivity of $R$. solani suspension at 0,12 , and $24 \mathrm{~h}$ post-treatment (hpt). The experiments were repeated twice independently. In bar graphs, data presented are means \pm standard deviation (mean $\pm \mathrm{SD}$ ) of five biological replicates. Different letters indicate statistically significant differences among treatments, while the same letters signify no significant differences between them according to Tukey's honestly significant difference test $(p<0.05)$. In simple linear regression graphs, the linear fit regression line is presented as a dotted line, regression equation and $R^{2}$ are also presented within the graph. 


\section{5. $\mathrm{SiO}_{2} \mathrm{NPs}$ Enhanced the Germination, Root, and Shoot Length, and Vigor Indexes of Wheat Plants in Soil Inoculation with R. solani}

Treating wheat grains with $\mathrm{SiO}_{2}$ significantly increased the germinated grains compared with control (Figure 4A). Infected and treated grains with $\mathrm{SiO}_{2} \mathrm{NPs}$ at 50 and $100 \mu \mathrm{g} \mathrm{mL}^{-1}$ showed a higher germination percentage compared with infected and nontreated seeds (positive control). The highest germination percentage $98 \%$ was observed in non-infected wheat seeds that were treated with $\mathrm{SiO}_{2} \mathrm{NPs}$ at a concentration of $100 \mu \mathrm{g} \mathrm{mL}^{-1}$. No significant effect was found between the germination (\%) of the negative control (untreated healthy seeds) and inoculated seeds that were treated with $100 \mu \mathrm{g} \mathrm{mL}^{-1} \mathrm{SiO}_{2} \mathrm{NPs}$ (Figure 4A).
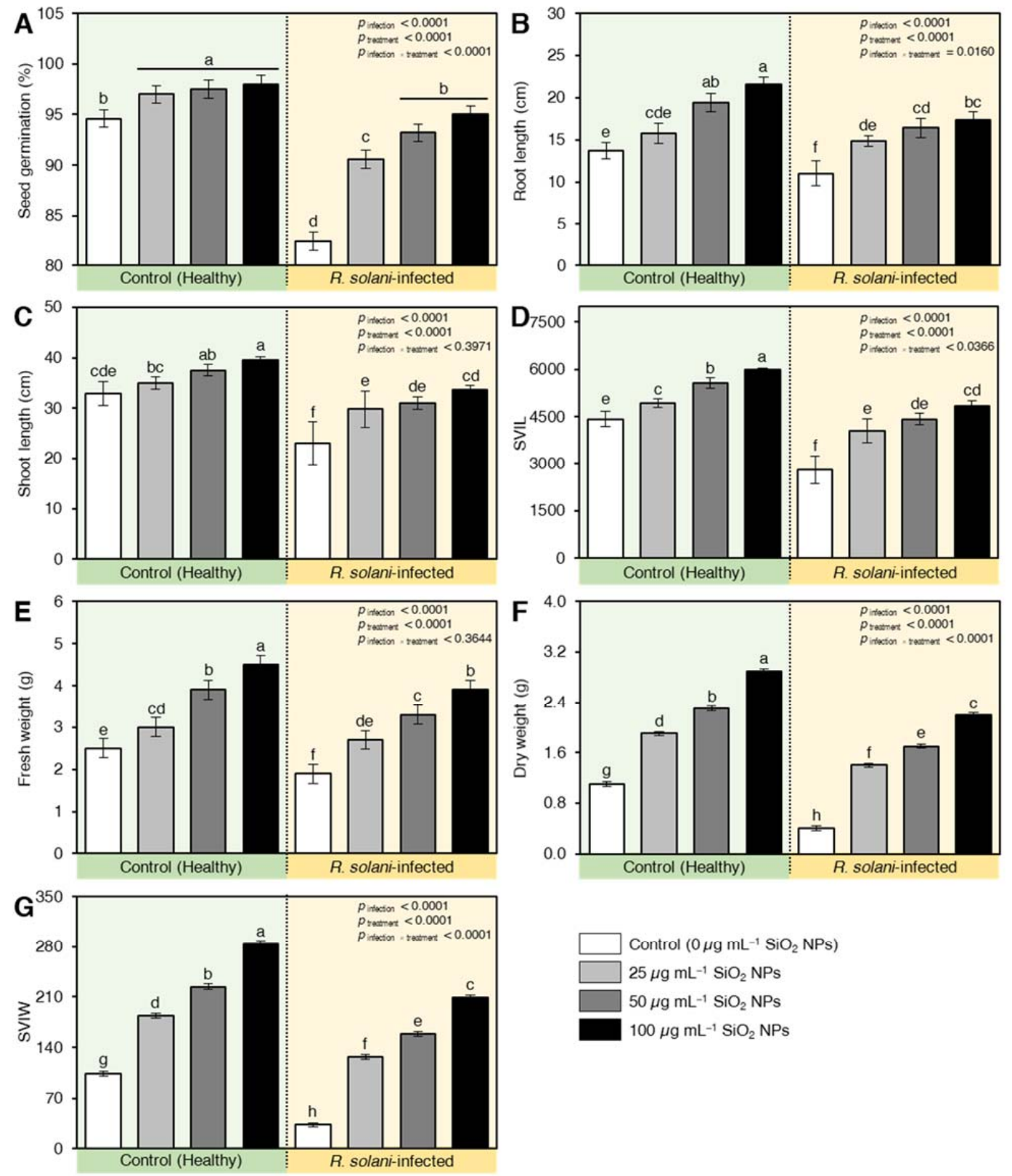

Figure 4. Effect of silicon dioxide nanoparticles $\left(\mathrm{SiO}_{2} \mathrm{NPs}\right)$ on vegetative traits of wheat plants under soil inoculation with R. solani. (A) seed germination (\%), (B) Root length, (C) Shoot length, (D) Seedling vigor index based on plant length (SVIL), (E) Fresh weight, (F) Dry weight, (G) Seedling vigor index based on plant wright (SVIW) of wheat seedlings infected with $R$. solani. Data presented are means \pm standard deviation (mean \pm SD) of five biological replicates. Different letters indicate statistically significant differences among treatments, while the same letters signify no significant differences between them according to Tukey's honestly significant difference test $(p<0.05)$. 
Likewise, $\mathrm{SiO}_{2} \mathrm{NPs}$ application significantly enhanced both root (Figure $4 \mathrm{~B}$ ) and shoot lengths (Figure $4 \mathrm{C}$ ) of both healthy and $R$. solani-infected seedlings. As a result, all tested concentrations of $\mathrm{SiO}_{2} \mathrm{NPs}$ significantly increased the vigor index based on root and shoot length (SVIL; Figure 4D) in both healthy and infected wheat seedlings. Applying $\mathrm{SiO}_{2}$ NPs at 50 and $100 \mu \mathrm{g} \mathrm{mL}^{-1}$ on healthy wheat seeds significantly increased SVIL values to 5552.9 and 5983.7, respectively. Additionally, treating infected wheat seeds with 50 and $100 \mu \mathrm{g} \mathrm{mL}^{-1} \mathrm{SiO}_{2} \mathrm{NPs}$ resulted in SVIL values of 4419.6 and 4840.9 , respectively, compared with 4413.4 for healthy untreated seedlings (negative control).

Similar results were observed in both seedling fresh weight (Figure 4E), seedling dry weight (Figure $4 \mathrm{~F}$ ), and when the seedling vigor index was measured based on seedling weight (SVIW; Figure 4G). The highest SVIW was noticed when healthy seeds were treated with $100 \mu \mathrm{g} \mathrm{mL}^{-1} \mathrm{SiO}_{2} \mathrm{NPs}$ (284.4) followed by $50 \mu \mathrm{g} \mathrm{mL}-1$ (224.4). All tested concentrations of $\mathrm{SiO}_{2}$ NPs significantly increased SVIW of inoculated seedlings compared with negative and positive controls (Figure 4G).

\section{6. $\mathrm{SiO}_{2} \mathrm{NPs}$ Application Reduced the Disease Parameters of $\mathrm{R}$. solani-Inoculated Wheat}

Soil infestation with $R$. solani significantly elevated pre-, post-emergence damping-off, and root rot percentages on inoculated wheat seedlings. $\mathrm{SiO}_{2} \mathrm{NPs}$ application showed reduced disease frequency and completely protected wheat seedlings at $100 \mu \mathrm{g} \mathrm{mL}$ (Figure 5A). Untreated wheat seedlings grown in R. solani-infested soil showed $17.6 \%$ preemergence compared to $5.4 \%$ in untreated healthy seedlings (Figure 5B). R. solani caused a significant increase in post-emergence damping-off and root rot (Figure 5C,D) recording $32.2 \%$ and $38.4 \%$, respectively, compared to $0 \%$ in the uninoculated negative control. In addition, treating the seeds with $\mathrm{SiO}_{2} \mathrm{NPs}$ significantly decreased the percentages of pre, post-emergence damping-off, and root rot compared to inoculated positive control. The highest concentration of $\mathrm{SiO}_{2} \mathrm{NPs} 100 \mu \mathrm{g} \mathrm{mL}^{-1}$ gave the lowest pre-emergence dampingoff $(5 \%)$, post-emergence damping-off $(5.2 \%)$, and root rot (8.4\%), followed by $\mathrm{SiO}_{2} \mathrm{NPs}$ at 50 and $25 \mu \mathrm{gL}^{-1}$.
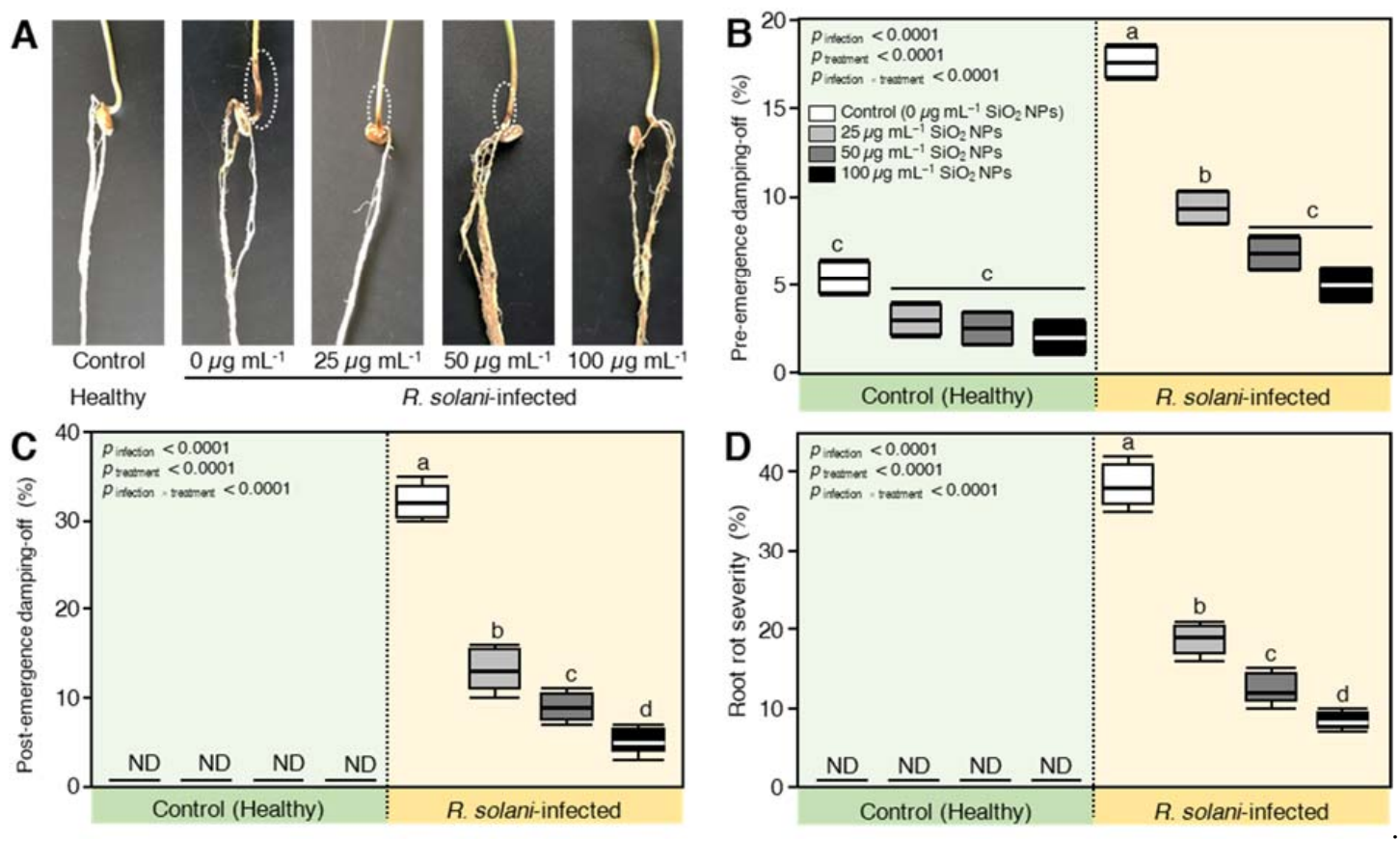

Figure 5. Effect of silicon dioxide nanoparticles $\left(\mathrm{SiO}_{2} \mathrm{NPs}\right)$ on damping-off severity of wheat seedlings infected by $R$. solani. (A) Healthy (negative control), $R$. solani-infected (positive control), and $\mathrm{SiO}_{2}$-treated wheat seedlings, (B) pre-emergence damping-off, (C) Post-emergence damping-off, and (D) Root rot severity. Whiskers show the minimum and the maximum values, horizontal thick lines indicate the medians, boxes signify the interquartile ranges (25th to 75th percentile of the data). Different letters indicate statistically significant differences among treatments, while the same letters signify no significant differences between them according to Tukey's honestly significant difference test $(p<0.05 ; n=5)$. 


\subsection{Effect of $\mathrm{SiO}_{2}$ NPs on the Biochemical Traits of Wheat Seedlings Inoculated with R. solani \\ 2.7.1. $\mathrm{SiO}_{2} \mathrm{NPs}$ Enhanced the Content of the Photosynthetic Pigment in \\ R. solani-Infected Plants}

Infection with $R$. solani adversely reduced the pigment content of infected wheat seedlings. In this regard, the chlorophyll $a$ (Figure 6A), chlorophyll $b$ (Figure 6B), and carotenoids (Figure 6C) were reduced in the positive control (infected untreated seedlings) by 30,30 , and $20 \%$ relative to the negative control (untreated uninfected seedlings). On the other hand, the seedlings treated with $\mathrm{SiO}_{2}$ NPS had a protective effect on wheat plants by alleviating the reduction of pigments contents higher than the healthy plants, which were witnessed at the level of $100 \mu \mathrm{g} \mathrm{mL}^{-1}$. The positive effect of $\mathrm{SiO}_{2} \mathrm{NPs}$ was also reported on the healthy plants and the effect intensified as the concentration of $\mathrm{SiO}_{2} \mathrm{NPs}$ increased (Figure 6).
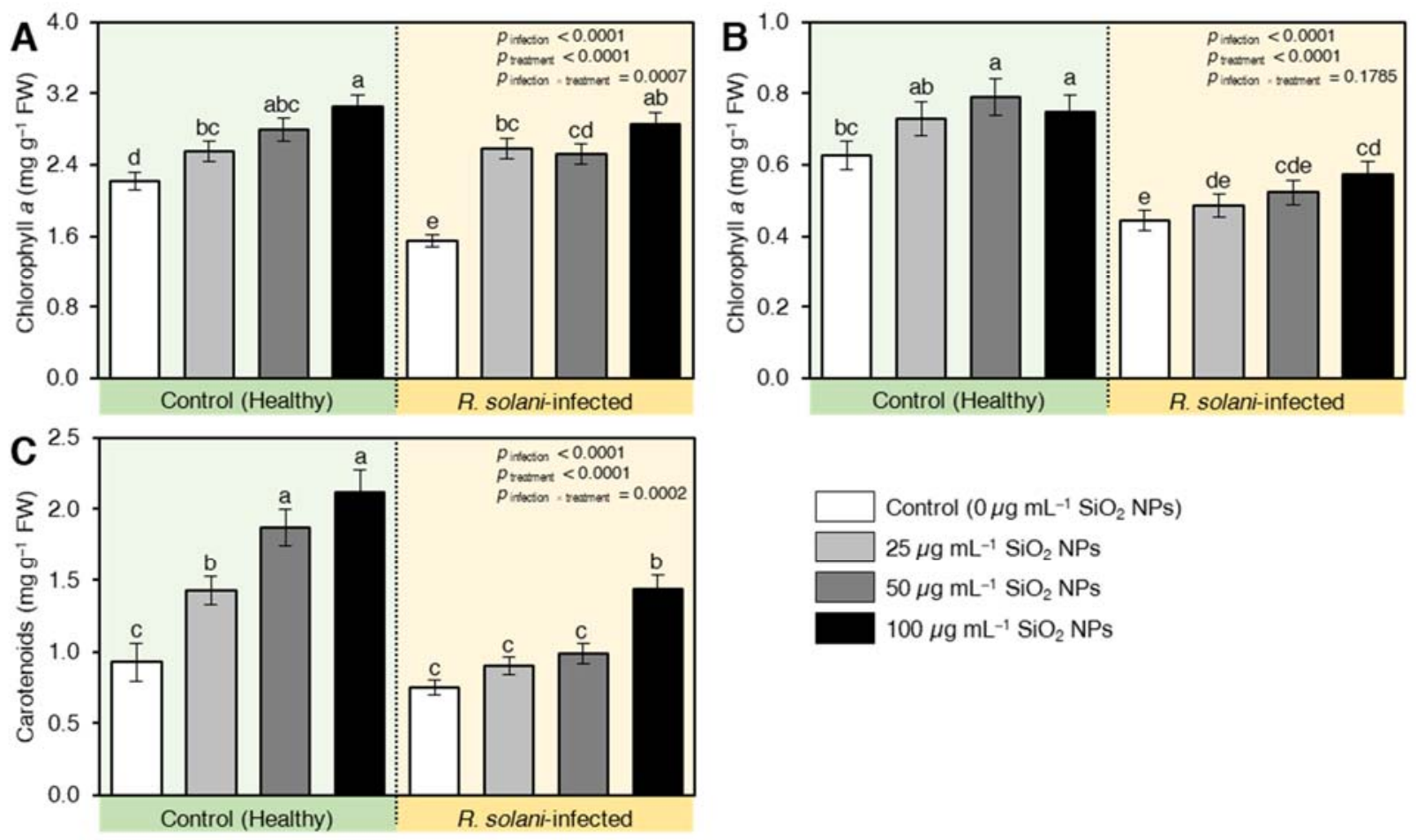

Figure 6. Effect of silicon dioxide nanoparticles $\left(\mathrm{SiO}_{2} \mathrm{NPs}\right)$ on the content of photosynthetic pigments of wheat seedlings infected by R. solani. (A) Chlorophyll $a\left(\mathrm{mg} \mathrm{g}^{-1} \mathrm{FW}\right),(\mathbf{B})$ Chlorophyll $b\left(\mathrm{mg} \mathrm{g}^{-1} \mathrm{FW}\right)$, and (C) Carotenoids (mg g $\left.{ }^{-1} \mathrm{FW}\right)$. Data presented are means \pm standard deviation (mean $\pm \mathrm{SD}$ ) of five biological replicates. Different letters indicate statistically significant differences among treatments, while the same letters signify no significant differences between them according to Tukey's honestly significant difference test $(p<0.05)$.

\subsubsection{Treatment with $\mathrm{SiO}_{2}$ NPs Alleviated the Oxidative Stress in R. solani-Infected Plants}

Infection with $R$. solani induced a high accumulation of hydrogen peroxide $(129 \%$; Figure 7A), superoxide anions (27\%; Figure 7B), and hydroxyl radicals (17\%; Figure 7C) compared with healthy plants (negative control). This effect was retarded by the applied levels of $\mathrm{SiO}_{2}$ NPS where the values of reactive oxygen species were lower than healthy plants (Figure 7). Likewise, the results deduced that $R$. solani enhanced lipid peroxidation (56\%; Figure 7D) and the contents of methylglyoxal (95\%; Figure 7E) relative to healthy plants (Figure 7). It is worthy to mention that applying $\mathrm{SiO}_{2} \mathrm{NPs}$ with different concentrations decreased the peroxidation of lipids and methylglyoxal compared to pathogen-infected plants and the lowest reduction was recorded for the level of $100 \mu \mathrm{g} \mathrm{mL}^{-1}$ where lipid peroxidation and methylglyoxal increased only by 7.3 and $18.8 \%$ higher than healthy plants and decreased by $30 \%$ and $36.8 \%$ compared with the infected control, respectively (Figure 7). 

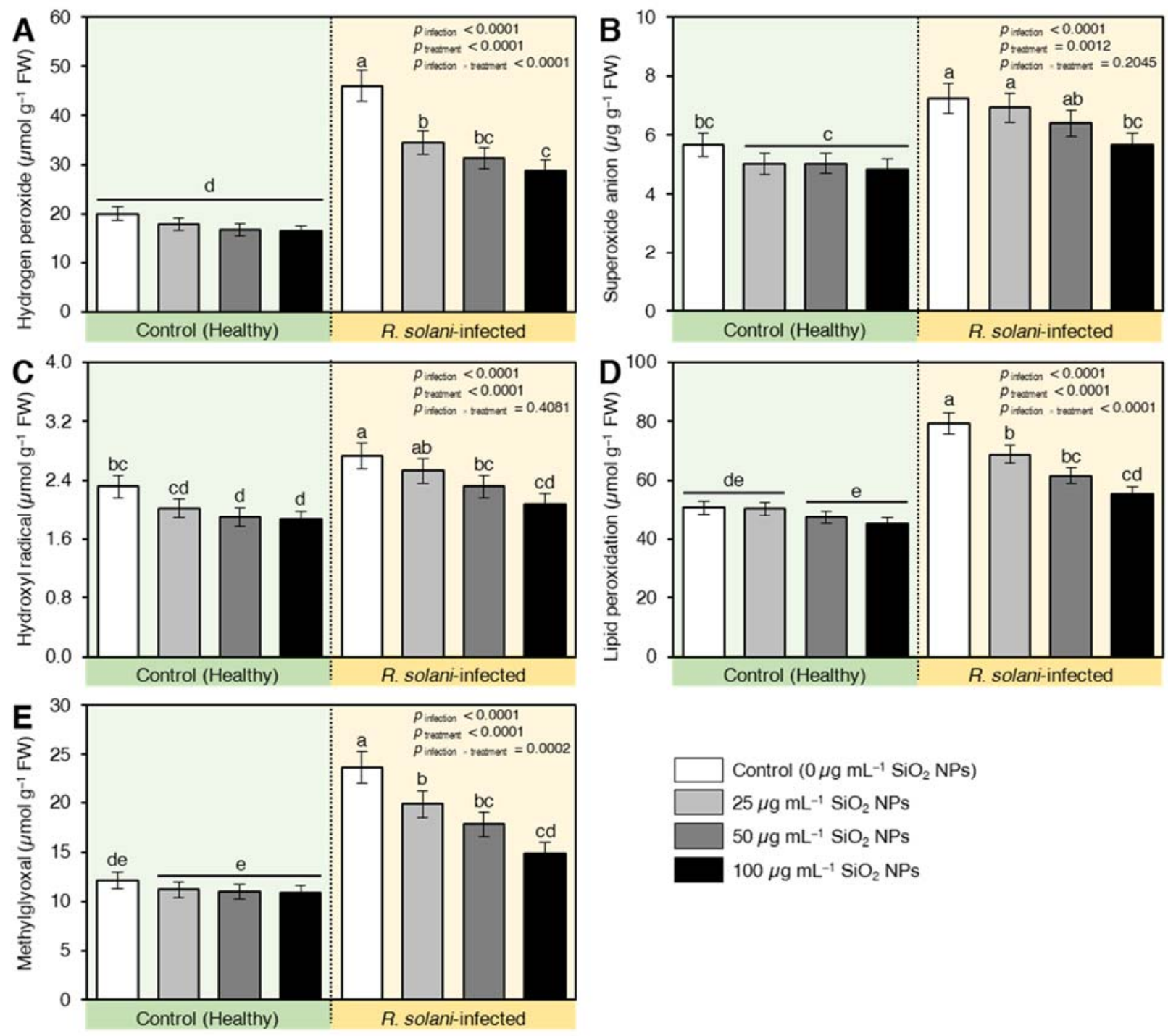

Figure 7. Effect of silicon dioxide nanoparticles $\left(\mathrm{SiO}_{2} \mathrm{NPs}\right)$ on oxidative stress-related compounds of wheat seedlings infected by R. solani. (A) Hydrogen peroxide ( $\left.\mu \mathrm{mol} \mathrm{g}^{-1} \mathrm{FW}\right),\left(\right.$ B) Superoxide anion $\left(\mu \mathrm{g} \mathrm{g}{ }^{-1} \mathrm{FW}\right),($ C) Hydroxyl radical $\left(\mu \mathrm{mol} \mathrm{g}{ }^{-1} \mathrm{FW}\right),\left(\right.$ D) Lipid peroxidation $\left(\mu \mathrm{mol} \mathrm{g}{ }^{-1} \mathrm{FW}\right)$, and (E) Methylglyoxal $\left(\mu \mathrm{mol} \mathrm{g}^{-1} \mathrm{FW}\right)$. Data presented are means \pm standard deviation (mean $\pm \mathrm{SD}$ ) of five biological replicates. Different letters indicate statistically significant differences among treatments, while the same letters signify no significant differences between them according to Tukey's honestly significant difference test $(p<0.05)$.

2.7.3. $\mathrm{SiO}_{2} \mathrm{NPs}$ Induced the Accumulation of Defense-Related Compounds in $R$. solani-Infected Seedlings

It is worth mentioning that the infection with $R$. solani significantly increased secondary metabolites and defense-related compounds. The infection increased the contents of total flavonoids (Figure 8A) and total phenolics (Figure 8B) by about 54 and 38\%, respectively, relative to the healthy plants. However, the utilization of different levels of $\mathrm{SiO}_{2}$ NPs instigated the secondary metabolites in healthy and infected plants. The exposure of seedlings to $100 \mu \mathrm{g} \mathrm{mL}^{-1}$ had a prominent role relative to other levels for inducing secondary metabolites (Figure 8). At the same time, the application of $\mathrm{SiO}_{2} \mathrm{NPs}$ significantly enhanced the accumulation of salicylic acid in infected seedlings, but not healthy ones (Figure 8C). The application of $\mathrm{SiO}_{2} \mathrm{NPs}$ at the levels of 50 and $100 \mu \mathrm{g} \mathrm{mL}^{-1}$ elevated the reduction in SA content in infected plants to a higher level than in healthy plants. Moreover, the activity of phenylalanine ammonia-lyase (PAL; a key SA biosynthesis enzyme) was 
negatively affected by $R$. solani. The applied protectant increased the PAL activity, and the enhanced value was intensified as the concentration of $\mathrm{SiO}_{2} \mathrm{NPs}$ increased (Figure 8D).
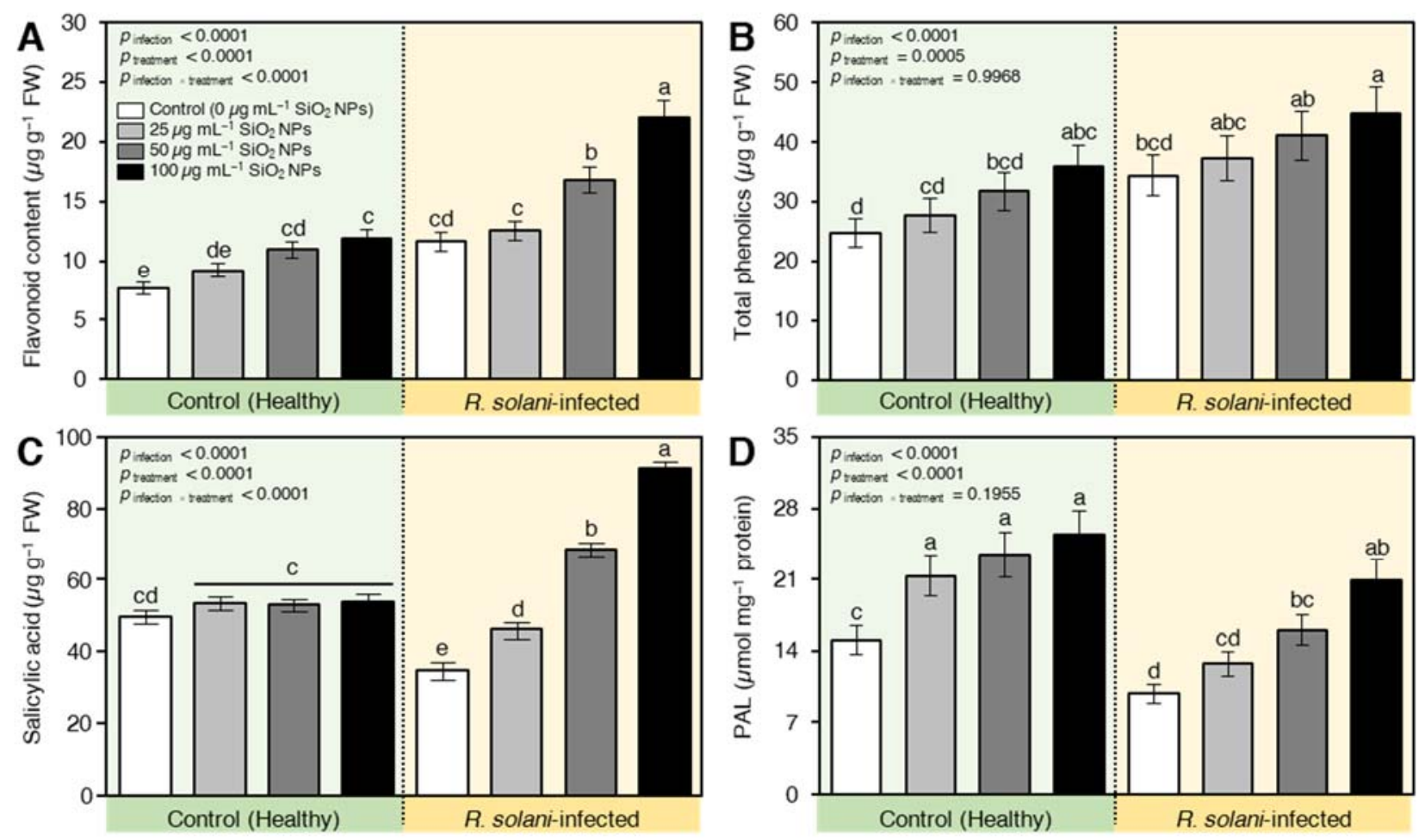

Figure 8. Effect of silicon dioxide nanoparticles $\left(\mathrm{SiO}_{2} \mathrm{NPs}\right)$ on defense-related compounds in wheat seedlings infected by $R$. solani. (A) Flavonoid content ( $\left.\mu \mathrm{g} \mathrm{g}{ }^{-1} \mathrm{FW}\right),\left(\right.$ B) Total phenolics $\left(\mu \mathrm{g} \mathrm{g}^{-1} \mathrm{FW}\right),\left(\right.$ C) Salicylic acid $\left(\mu \mathrm{g} \mathrm{g}{ }^{-1} \mathrm{FW}\right)$, and (D) phenylalanine ammonia-lyase (PAL; a key SA biosynthesis enzyme) ( $\mu \mathrm{mol} \mathrm{mg} \mathrm{m}^{-1}$ protein). Data presented are means \pm standard deviation (mean $\pm \mathrm{SD}$ ) of five biological replicates. Different letters indicate statistically significant differences among treatments, while the same letters signify no significant differences between them according to Tukey's honestly significant difference test $(p<0.05)$.

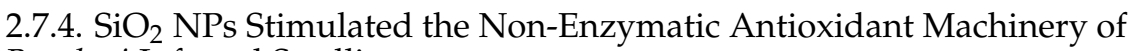
R. solani-Infected Seedlings

The non-enzymatic antioxidants, such as nitric oxide (Figure 9A), ascorbic acid (vitamin C; Figure 9B), and glutathione (GSH; Figure 9C) were found at lower levels in nontreated R. solani-infected seedlings. However, these harmful effects were neutralized upon $\mathrm{SiO}_{2} \mathrm{NPs}$ application (Figure 9) in infected plants. For instance, nitric oxide (NO) recorded lower values for only $R$. solani-infected plants. The used applicants increased the NO content of wheat leaves compared to infected plants only (Figure 9A). The highest induction was recorded also for the level of $100 \mu \mathrm{g} \mathrm{mL} \mathrm{m}^{-1} \mathrm{SiO}_{2} \mathrm{NPs}$. Likewise, the pool of ascorbic acid content was significantly increased by the application of $\mathrm{SiO}$ NPs. Intriguingly, ascorbic acid recorded a high value under the interactive effect of $100 \mu \mathrm{g} \mathrm{mL}{ }^{-1} \mathrm{SiO}_{2}$ NPs and pathogen-infected plants compared with infected and nontreated control (positive control) (Figure 9B). Similarly, reduced glutathione (GSH) in the infected plants seems to be deregulated by $R$. solani infection where the lowest values were obtained. The GSH levels were increased after the application of nanomaterial with high alleviation capacity at the concentration of $100 \mu \mathrm{g} \mathrm{mL} \mathrm{miO}_{2}^{-1} \mathrm{NPs}$ (Figure 9C). 

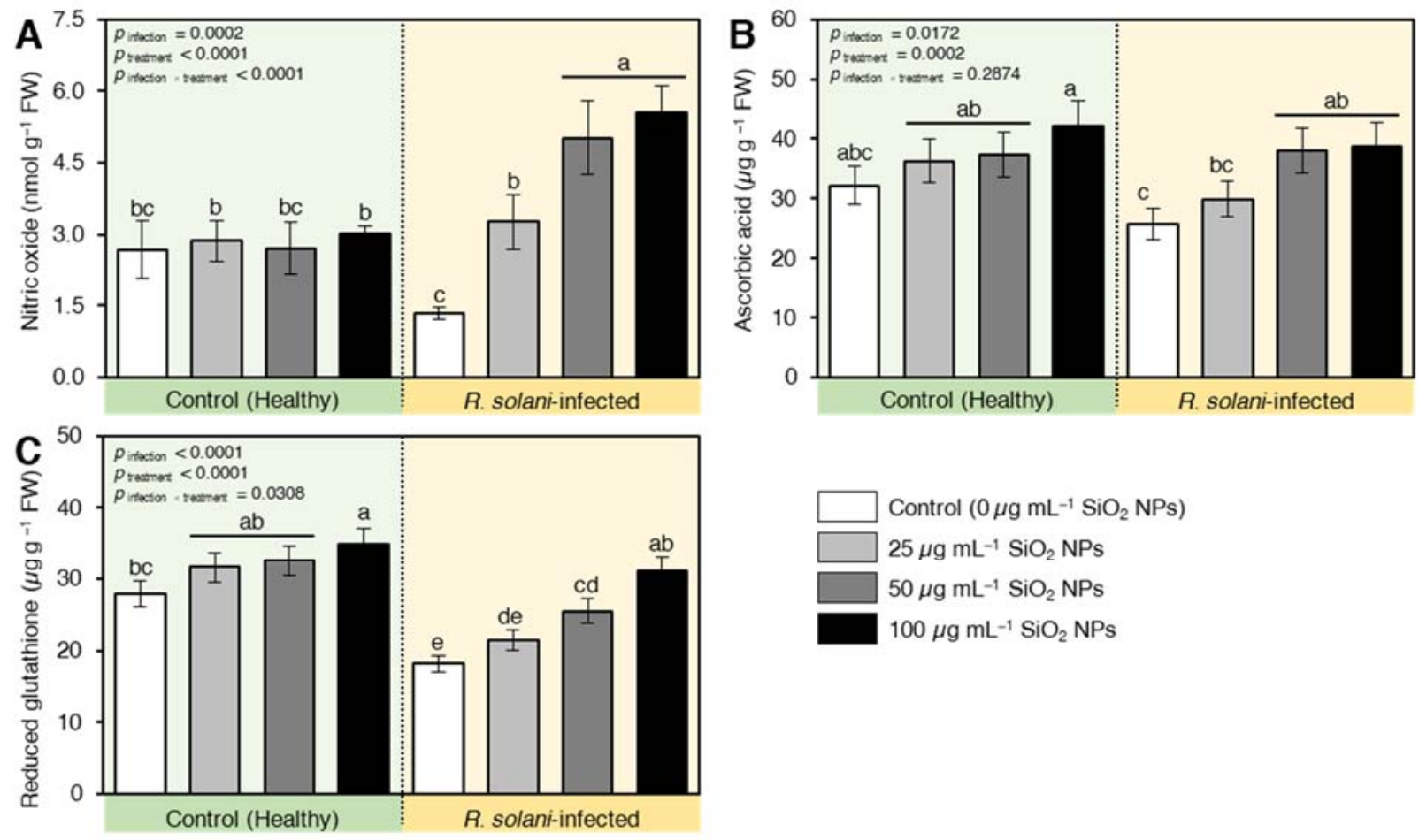

Figure 9. Effect of silicon dioxide nanoparticles $\left(\mathrm{SiO}_{2} \mathrm{NPs}\right)$ on the non-enzymatic antioxidant machinery of $R$. solani-infected seedlings. (A) Nitric oxide ( $\left.\mathrm{nmol} \mathrm{g}^{-1} \mathrm{FW}\right),\left(\right.$ B) Ascorbic acid $\left(\mu \mathrm{g} \mathrm{g}^{-1} \mathrm{FW}\right)$, and (C) Reduced glutathione ( $\left.\mu \mathrm{g} \mathrm{g}{ }^{-1} \mathrm{FW}\right)$. Data presented are means \pm standard deviation (mean $\pm \mathrm{SD}$ ) of five biological replicates. Different letters indicate statistically significant differences among treatments, while the same letters signify no significant differences between them according to Tukey's honestly significant difference test $(p<0.05)$.

\subsection{5. $\mathrm{SiO}_{2} \mathrm{NPs}$ Induced the Enzymatic Antioxidant Machinery of R. solani-Infected Seedlings}

The antioxidant enzymes responded differentially to R. solani infection. SOD (Figure 10A) and POD (Figure 10B) activities were increased by 11 and $46 \%$, respectively, relative to healthy plants. On the other hand, the activities of both APX (Figure 10C) and CAT (Figure 10D) were reduced by 21 and $10 \%$, respectively, due to R. solani infestation. Nevertheless, the application of $\mathrm{SiO}_{2} \mathrm{NPs}$ induced the antioxidant enzymes by restricting the reduction of APX and CAT and exacerbated the content of SOD compared to infected and healthy plants. It is worth mentioning that the activity of POD was kept at the level of infected plants under the interactive effect of $\mathrm{SiO}_{2} \mathrm{NPs}$ and $R$. solani infection, but higher than control plants. The healthy plants treated with $\mathrm{SiO}_{2} \mathrm{NPs}$ recorded higher activities of POD, APX and CAT compared to non-treated healthy plants. The activity of SOD in infected plants was kept at levels similar to the control irrespective of the level of $\mathrm{SiO}_{2} \mathrm{NPs}$ applied (Figure 10). Similarly, polyphenol oxidase (PPO) activity was found to be at the lowest content for healthy plants receiving no nano-silicon treatments (Figure 10E). On the other hand, $R$. solani enhanced the PPO activity and the application of $\mathrm{SiO}_{2} \mathrm{NPs}$ reduced PPO in infected plants compared with infected and nontreated control especially at the highest concentrations $100 \mu \mathrm{g} \mathrm{mL}{ }^{-1}$. 

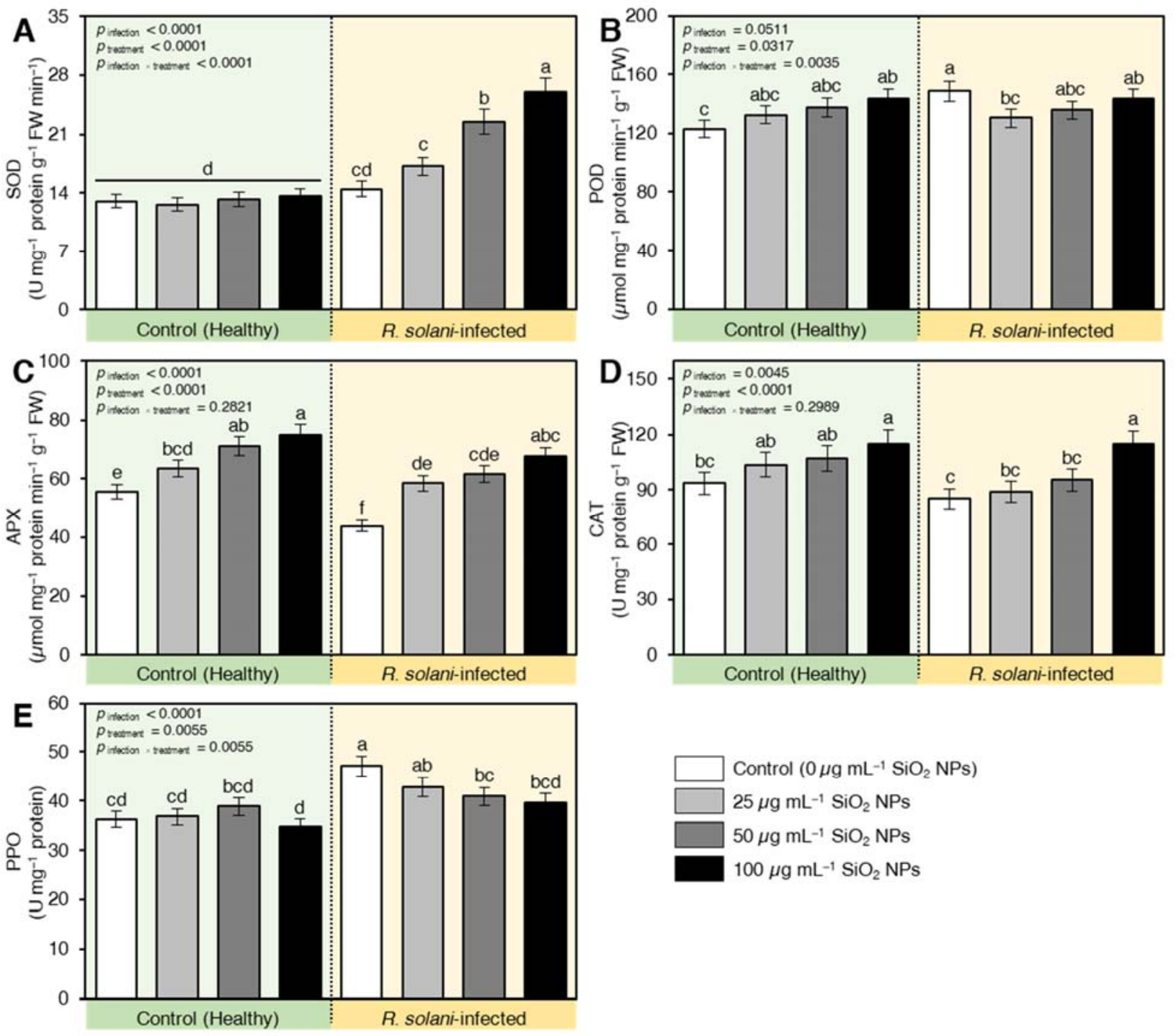

Figure 10. Effect of silicon dioxide nanoparticles $\left(\mathrm{SiO}_{2} \mathrm{NPs}\right)$ on enzymatic antioxidant machinery of $R$. solani-infected seedlings. (A) Superoxide dismutase (SOD), (B) Guaiacol peroxidase (POD), (C) Ascorbate peroxidase (APX), (D) Catalase $(\mathrm{CAT})$, and (E) Polyphenol oxidase (PPO). Data presented are means \pm standard deviation (mean \pm SD) of five biological replicates. Different letters indicate statistically significant differences among treatments, while the same letters signify no significant differences between them according to Tukey's honestly significant difference test $(p<0.05)$.

\section{Discussion}

Spherical shaped nano silicon dioxide $\left(\mathrm{SiO}_{2}\right)$ particles were successfully biosynthesized during this study using saffron extraction. The role of saffron in the biosynthesis of metal oxides nanoparticles was explained as the extract of saffron petals contains hydroxyl groups from several phenolic compounds, such as flavonoids like kaempferol and anthocyanins like anthocyanidin, delphinidin, and pelargonidin. These hydroxyl groups enhance saffron's ability for the biosynthesis of metal NPs, as it binds with metal ions and acts as a reducing agent for the reduction of metal crude particles to metal NPs [31,32]. It was previously inferred that biosynthesis of nanoparticles improves the physicochemical characteristics of particles, such as the surface area-to-volume ratio and enhances the stability of the structure that improves the anti-microbial activity of the nanometals against plant pathogens.

In this study, $\mathrm{SiO}_{2} \mathrm{NPs}$ were biosynthesized using saffron extract. The maximum peak of $\mathrm{SiO}_{2} \mathrm{NPs}$ was observed at approximately $440 \mathrm{~nm}$, which is almost the same finding 
as reported by Tripathi et al. [33]. FTIR spectroscopy uses wavelength to measure the absorption of infrared radiation by tested samples, the reading of the infrared spectrum includes the interpretation of the correlation between the absorption bands (vibration bands) and the chemical compounds in the sample. The spectra of $\mathrm{SiO}_{2} \mathrm{NPs}$ showed a band around $1103 \mathrm{~cm}^{-1}$ which corresponds to the asymmetric stretching vibration of Si-OSi [34-36]. A wide absorption range was observed at 1634 and $3405 \mathrm{~cm}^{-1}$ that indicates the presence of $\mathrm{H}-\mathrm{O}-\mathrm{H}$ stretching and bending of absorbed water $[37,38]$. The observed peaks at $801 \mathrm{~cm}^{-1}$ are assigned to the Si-OH bond [34,36].

The broadband detected with XRD which showed reflection at $2 \Theta=22.8^{\circ}$ and the strong absorption band at $440 \mathrm{~nm}$ by UV-vis indicated that amorphous $\mathrm{SiO}_{2}$ nanoparticles were successfully synthesized [33,39]. Additionally, no additional peaks were observed in the XRD spectrum which indicates there are no impurities in the obtained $\mathrm{SiO}_{2} \mathrm{NPs}$. Additionally, the percentage of each element was calculated using the energy dispersion spectrum (EDS) which showed that $\mathrm{SiO}_{2} \mathrm{NPs}$ contained $29 \% \mathrm{Si}$ and $71 \% \mathrm{O} . \mathrm{SiO}_{2} \mathrm{NPs}$ sized between 20 and $95 \mathrm{~nm}$ were synthesized by sol-gel method using sodium silicate [33]. According to UV-Vis, FTIR, XRD, and TEM images, using saffron extraction in the biosynthesis of $\mathrm{SiO}_{2}$ NPs resulted in smaller particle sizes 9.92 to $19.8 \mathrm{~nm}$ with safer and fewer coast methods.

The importance of $\mathrm{SiO}_{2}$ NPs lays in their dual effect on both pathogen and host plant. On the pathogen side, silicon dioxide nanoparticles showed high antifungal activity against $R$. solani and completely inhibited its growth at $100 \mu \mathrm{g} \mathrm{mL}-1$. The antifungal effect of $\mathrm{SiO}_{2}$ NPs against the human pathogenic Trichoderma Harzianum and Rhizoctonia species was previously reported by Verma and Bhattacharya [35]. Moreover, Derbalah et al. stated that $\mathrm{SiO}_{2}$ NPs showed an antifungal effect against Alternaria solani, which significantly inhibited the growth of Alternaria mycelium and reduced the severity of early blight disease on tomato plants [40].

Various theories explained the fungicidal effect of silicon nanoparticles. The accumulation of $\mathrm{SiO}_{2} \mathrm{NPs}$ in the membrane of the fungal cell wall may result in the lysis of the cells, blockage of the transmembrane energy cycle, disruption of the electron transport chain, or oxidation of the cell membrane by forming insoluble compounds in the cell membrane. $\mathrm{SiO}_{2}$ NPs interact with protein thiol groups $(-\mathrm{SH})$ on the fungal cell surface leading to cell lysis due to its positive charge [40]. Silicon nanoparticles may deactivate the protein molecules and directly bind with fungal DNA causing mutation and affecting replication [41]. Furthermore, hydroxyl groups on the surface of small particles of silicon bind with lipopolysaccharides of the fungal cell wall and cause a breakdown of treated fungal cells [42]. In this study, the loss of integrity of $R$. solani cell wall and cell membrane was confirmed by leakage of cellular materials, which resulted in changes in extracellular conductivity.

On the host plant side, It is well-documented that silicon application positively increases the host plant resistance against phytopathogens and plays important role in the interaction between the host plant and the pathogen [43]. Additionally, it decreases the severity of fungal diseases and induced resistance against a wide range of plant pathogenic fungi that cause root and foliar diseases [25,44]. It is worth mentioning that biosynthesized $\mathrm{SiO}_{2}$ NPs showed decreased pre-, post-emergence damping-off and root rot percentages of infected wheat seedlings in the current study. This might be due to the negative effects of $\mathrm{SiO}_{2} \mathrm{NPs}$ on the fungal pathogen since our findings showed a strong dose-dependent fungistatic activity against $R$. solani in vitro. For instance, the highest concentration of $\mathrm{SiO}_{2}$ $\left(100 \mu \mathrm{g} \mathrm{mL}^{-1}\right)$ showed no mycelial growth (100\% growth reduction) of $R$. solani.

Moreover, the suppression of pre-, post-emergence damping-off and root rot severity caused by $\mathrm{SiO}_{2} \mathrm{NPs}$ could be attributed to its contribution to different defense mechanisms. One of the defense mechanisms that could be expressed by silicon is the formation of physical barriers through Si accumulation below the cuticle and in cell walls, which contributed to preventing or delaying the penetration of infection pegs of $R$. solani appressoria $[45,46]$. 
Additionally, silicon effectively prevents fungal ingress by the formation of a Si-enriched layer and the uniform distribution of Si aggregates [43,44].

The accurate biological mechanisms of potential interaction between silicon and different biochemical pathways that lead to plant resistance to fungal pathogens remain unclear [46]. The defense mechanisms induced by silicon involve rapid production of defense compounds, i.e., phenolics, flavonoids, anthocyanins, lignin, callose, and phytoalexins through primary, as well as secondary metabolic pathways, also silicon increased activities of defense enzymes, such as phenylalanine ammonia-lyase (PAL), polyphenol oxidase (PPO), peroxidase (POX), lipoxygenase (LOX), chalcone synthase (CHS) chalcone isomerase, $\beta$-1,3-glucanase (GLU), pathogenesis-related (PR) proteins and chitinases [47-49]. Interestingly, our findings showed that $\mathrm{SiO}_{2} \mathrm{NPs}$ application simultaneously activated multiple defense mechanisms in treated wheat seedlings. These mechanisms involve (i) the induction of defense-related compounds, particularly SA accumulation and its major biosynthetic enzyme PAL, and (ii) activation of both enzymatic (POD, SOD, APX, CAT, and PPO) and non-enzymatic (phenolics and flavonoids) antioxidant defense machinery.

In addition, the alteration of membrane phospholipids acts as signaling components during $R$. solani infection. In the current study, the infected plants suffered from high damage of the membrane by exacerbation of lipid peroxidation content, which was repeatedly outlined in the literature as an indicator of the oxidative burst in stressed plants [50]. Methylglyoxal (MG) accumulation was shown to be correlated with increased intracellular oxidative stress, due to enhanced reactive oxygen species (ROS) production [50]. The studied plants encountered a high accumulation of MG content under $R$. solani infection.

The excessive MG accumulation in plant cells under infection by $R$. solani can inhibit cell proliferation, chlorophyll biosynthesis, instigate the deactivation and/or degradation of proteins, as well as antioxidant defending products, leading to disruption of many cellular functions [51]. All these deteriorations induced by $R$. solani were augmented by $\mathrm{SiO}_{2} \mathrm{NPS}$. The $\mathrm{SiO}_{2} \mathrm{NPs}$ upregulated the content of MG and lipid peroxidation concomitant with reduction of ROS and augmentation of antioxidants and chlorophyll content. Thus, $\mathrm{SiO}_{2}$ NPs triggered better intact membrane structure through the reduction of the fluid structure of membrane lipids. The situation was confirmed by lower ROS, lipid peroxidation, and methylglyoxal activity. Thus, wheat plants respond to nanoparticles by fine-tuning redox homeostasis and so resist $R$. solani infection. Si and Si nanoparticles might play an important role in promoting protective mechanisms to decline membrane lipid peroxidation and electrolyte leakage through NO-signaling [33].

Moreover, the interaction between salicylic acid (SA) and reactive oxygen species (ROS) is well-documented [52]. The SA-ROS plays a key role in the transcriptional reprogramming that occurs during the plant defense responses. Briefly, biotic stress, such as exposure to phytopathogenic fungi, triggers ROS production mainly at the apoplast [52]. As a result, plants try to defend themselves via multilayered defense mechanisms in a spatio-temporal manner via an SA-mediated pathway [52]. It is worth mentioning that SA not only has a pro-oxidant role, but it also plays an antioxidant role concertedly with glutathione (GSH) [52]. Interestingly, our findings showed that while infection with $R$. solani induced a high accumulation of hydrogen peroxide, superoxide anions, and hydroxyl radical compared with healthy plants, $\mathrm{SiO}_{2} \mathrm{NPs}$ application reduced the ROS levels and induced the accumulation of defense-related compounds, particularly SA, in $R$. solani-infected seedlings. Collectively, these findings suggest that $\mathrm{SiO}_{2} \mathrm{NPs}$ application might activate a feed-forward loop between ROS and SA in response to pathogen infection. However, further studies are required to better understand the molecular mechanisms of $\mathrm{SiO}_{2} \mathrm{NPs}$ in the stimulation of SA-ROS interplay.

Furthermore, the utilization of $\mathrm{SiO}_{2} \mathrm{NPs}$ had a regulatory role in stimulating the biosynthesis of ascorbate as an antioxidant molecule that keeps ROS (superoxide anion, hydrogen peroxide, and hydroxyl radical) at lower levels than the infected plants in a concentration-dependent manner where $100 \mathrm{mg} \mathrm{L}^{-1}$ was the most effective concentration. Similarly, our findings showed that $R$. solani infection shifted the cellular redox balance 
toward a more oxidative state, including a decline of the GSH pool, affecting all cellular compartments, and ROS detoxification. A similar reduction was reported for onion under Fusarium oxysporum infection [53].

Moreover, our findings showed that although $R$. solani significantly stimulated the content of the superoxide anions, the activity of $\mathrm{SOD}$ was enhanced upon $\mathrm{SiO}_{2} \mathrm{NPs}$ application. On the other hand, the high accumulation of $\mathrm{H}_{2} \mathrm{O}_{2}$ was ascribed to the reduction of CAT and APX activities in non-treated infected plants, suggesting the sensitivity of the studied plants to infection by $R$. solani and breakdown of main defense strategies, which weaken the resistance of plants. However, $\mathrm{SiO}_{2} \mathrm{NPs}$ application significantly induced the activities of SOD, CAT, and APX in connection with the reduction of disease severity, ROS, and membrane deterioration traits (lipid peroxidation and methyloxyal). Furthermore, enhanced antioxidant enzymes activities played a key regulatory role in plant growth, photosynthetic rate, cellular redox potential, and membrane integrity by eliminating free radicals [54]. Our findings showed that Si NPs significantly improved activities of SOD, APX, CAT, and GPX, which further counterbalance ROS as indicated by lower lipid peroxidation and electrolyte leakage [33]. Collectively, our findings indicate that $\mathrm{SiO}_{2} \mathrm{NPs}$ enhance the wheat defense response against $R$. solani via upregulation of both enzymatic and non-enzymatic antioxidant defense machinery.

Apart from their role in catalyzing the breakdown of $\mathrm{H}_{2} \mathrm{O}_{2}$, PODs were reported to be involved in lignification and suberization processes [55]. POD activity of all $\mathrm{SiO}_{2}$ NPs-treated plants under stress was lower than that of the control levels. Decreased activity of POD revealed that using $\mathrm{SiO}_{2} \mathrm{NPs}$ might reduce lignification processes resulting from $R$. solani infection. Therefore, $\mathrm{SiO}_{2} \mathrm{NPs}$ can reduce stress severity where there is no need for high lignification as reported by Bagy et al. [55] who reported that mycorrhizal fungi and entophyte reduce the content of soluble and ionic peroxidases and lignification under Pectobacterium infection.

In the present study, $R$. solani stimulated the production of phenolic compounds of wheat plants compared to healthy plants concomitant with enhanced peroxidase activity. Thus, the accumulation of phenolic compounds is a positive sign of stimulation of resistance by $\mathrm{SiO}_{2} \mathrm{NPs}$, which significantly exacerbated phenolic compound production higher than in infected plants. Using nano-silica increased the contents of phenolics similar to the studies of $[56,57]$. Moreover, $\mathrm{SiO}_{2} \mathrm{NPs}$ application significantly induced the accumulation of defense-related compounds in $R$. solani-infected seedlings, particularly SA. SA is a defense-associated phytohormone that is mainly involved in plant responses to biotrophic and necrotrophic pathogens [58-61]. Furthermore, the major SA-biosynthetic enzyme, $\mathrm{PAL}$, was dramatically reduced by infection; however, $\mathrm{SiO}_{2} \mathrm{NPs}$ promptly augmented the reduction of PAL under stress and further enhanced the activity of PAL, which is concomitant with the high induction of phenolic compounds and flavonoids. PAL is involved in the synthesis of plant secondary antimicrobial substances and it is essential for plant disease resistance responses [53] and plays an essential role in the biosynthesis of the precursors of lignin [62].

Plant defense via lignification is a conserved basal mechanism in the plant immune response against pathogens [63]. Silicon increases the transcript abundance of PAL in rice plants, leading to enhanced lignification [64], while $\mathrm{SiO}_{2}$ NPs enhance PAL expression and lignification in the leaves and roots of oat seedlings [65]. The reduction of disease severity in rice [66] and cucumber [67] by silicon pre-treatment has been attributed to an increase in the activities of PPO and PAL. Therefore, the increase in the activity of PPO and PAL in the present study could prevent the pathogenic infection in beetroot due to silicon supplementation.

PPO activity was significantly stimulated upon treatment with $\mathrm{SiO}_{2} \mathrm{NPs}$ during fungal infection compared with healthy plants. This role of $\mathrm{SiO}_{2} \mathrm{NPs}$ revealed that the $\mathrm{SiO}_{2} \mathrm{NPs}$ reduced the pathogenesis, so the need for higher PPO in infected plants is not needed. PPO is a defense enzyme associated with fostering host resistance because it can catalyze the final step of lignin biosynthesis [62], and oxidize phenolic compounds 
to quinones [55]. The resulting quinones are toxic to invading organisms [68], hence possessing antipathogenic properties [69]. Consequently, $\mathrm{SiO}_{2} \mathrm{NPs}$ treatment reduces the severity of invading microorganisms and enhances suitable defending agents that support plant immunity. POD, PPO, and PAL defense enzymes are generally working together for enhancing plant resistance to pathogens. This conclusion was recommended for infected plants treated with $\mathrm{SiO}_{2} \mathrm{NPs}$ that had adequate PPO and PAL activities, which aided in preventing further development of infection.

\section{Materials and Methods}

\subsection{Biosynthesis of Silicon Dioxide $\left(\mathrm{SiO}_{2}\right)$ Nanoparticles}

4.1.1. Preparation of Aqueous Saffron Extraction

The aqueous saffron extraction was prepared as described by Nagaonkar et al. [70] with slight modification. Briefly, one gram of dried saffron stigmas (Qingdao Jingtai Huacheng International Trad Co., Ltd., Qingdao, Shandong, China) was suspended in $100 \mathrm{~mL}$ of deionized water. The mixture was homogenized and kept at $60^{\circ} \mathrm{C}$ for $6 \mathrm{~h}$. The obtained extract was filtered three times using Whatman filter paper no. 1 and further used in the process of synthesis of $\mathrm{SiO}_{2} \mathrm{NPs}$.

\subsubsection{Synthesis of $\mathrm{SiO}_{2}$ Nanoparticles}

$\mathrm{SiO}_{2} \mathrm{NPs}$ were prepared following the protocols described previously [71-73] with slight modifications. Briefly, $100 \mathrm{~mL}$ of the aqueous saffron extract was mixed with $100 \mathrm{~mL}$ of $0.1 \mathrm{M}$ bulk $\mathrm{SiO}_{2}$ (Qingdao Jingtai Huacheng International Trad Co., Ltd. Model No. XR.16, Silicon Dioxide) solution. The prepared solution was stirred at $60{ }^{\circ} \mathrm{C}$ for $6 \mathrm{~h}$, then centrifuged at 10,000 rpm for $10 \mathrm{~min}$. The supernatant was discarded and the pellets were collected and lyophilized to obtain the powder.

\subsubsection{Characterization of $\mathrm{SiO}_{2}$ Nanoparticles}

Analysis of Ultraviolet Spectra

$\mathrm{SiO}_{2}$ NPs were checked at a wavelength ranging from 200 to $800 \mathrm{~nm}$ for the highest peak absorption using UV-Vis spectroscopy (Shimadzu Spectrometer, Shimadzu Corporation, Kyoto, Japan) [74].

\section{Fourier Transform Infrared Spectroscopy (FTIR)}

Formation of $\mathrm{SiO}_{2}$ NPs was detected in the collected powder using FTIR analysis at a range of $400-4000 \mathrm{~cm}^{-1}$ regions using Fourier transform infrared spectrometer (Vector 22, Bruker, Germany) at a resolution of $4 \mathrm{~cm}^{-1}$.

\section{X-ray Diffraction (XRD)}

The purity of extracted particles was tested using an X-ray diffractometer (XRD) by fixing a coated film of dried $\mathrm{SiO}_{2} \mathrm{NPs}$ powder on glass slides with operating conditions of $45 \mathrm{kV}$ and $20 \mathrm{~mA}$ current with $\mathrm{Cu}-\mathrm{Ka}$ radiation as an X-ray source in the $20-80^{\circ}$ range at the $2 \Theta$ angle.

\section{Transmission Electron Microscopy (TEM)}

The transmission electron microscope JEM-1230, JEOL, Akishima, Japan, was used to detect the morphology of $\mathrm{SiO}_{2}$ nanoparticles. The samples were processed as described by Atallah et al. [75]. A film from the sample was placed in a grid box and the procedures recommended by the manufacturer were followed.

\subsection{Pathogen Isolate and Pathogenicity Test}

An isolate of $R$. solani was obtained from the Department of Plant Pathology, Minia University, Egypt. The isolate was previously identified at Molecular Biology Research Unit, Assiut University and SolGent Company, Daejeon South Kore based on sequence analysis of the internal transcribed spacer (ITS) region using ITS1 and ITS4 primers. The 
R. solani isolate was propagated on a PDA medium, incubated for seven days at room temperature $\left(28 \pm 2{ }^{\circ} \mathrm{C}\right)$, and used as an inoculum source for the inoculation of wheat seeds $[76,77]$.

The pathogenicity of $R$. solani isolate was tested on eight wheat cultivars namely Gemmiza-11, Gemmiza-12, Giza-168, Giza-171, Misr-1, Misr-2, Sids-13, and Sids-14. Briefly, sterilized soil was added to three-inches diameter pots. The inoculum of $R$. solani was cultured on barley grains was mixed with the soil at $1 \%(\mathrm{~W}: \mathrm{W})$. The infested pots were watered as needed and left for five days to enhance the establishment of $R$. solani growth in the soil. $1 \%$ sodium hypochlorite solution was used to surface sterilize the seeds of each wheat cultivar by immersing the seeds for $2 \mathrm{~min}$ in the solution. The seeds were then rinsed in sterile distilled water. Three seeds were sown in each pot. Five replicates were used for each treatment. Pots filled with non-infested soil were used as a negative control. The pots were randomly distributed within each plot. Pre-, post-emergence damping-off and root rot for wheat seedlings were evaluated two, four, and six weeks after the sowing date, respectively, according to Raju and Naik [78] and Beale et al. [79].

The pre- and post-emergence damping-off was calculated using Equation (1) as follows:

$$
\text { Damping }- \text { off }(\%)=\frac{\text { No. of infected plants }}{\text { total No. of plants }} \times 100
$$

Furthermore, the disease severity of root rot was assessed using the indexing method described by Beale et al. [79]. The roots of wheat plants were washed and divided into five categories according to the percentage of all roots with lesions typical of root rot: zero (0) trace to $10 \%(1),>10 \%$ and $\leq 30 \%(2),>30 \%$ and $\leq 60 \%$ (3), and $>60 \%$ (4). Disease severity percentage was calculated using Equation (2) as follows:

$$
\text { Disease severity }(\%)=\frac{(i \text { rating no } . \times \text { no. of plants in the rating })}{(\text { total no } . \text { of plants } \times \text { highest rating })} \times 100
$$

\subsection{In Vitro Antifungal Activity of $\mathrm{SiO}_{2}$ \\ 4.3.1. Effect of $\mathrm{SiO}_{2}$ NPs on the Linear Growth of $R$. solani}

The experiment was implemented as described by Joshi et al. [80] with minor modifications. Potato dextrose agar (PDA) medium was prepared, and $\mathrm{SiO}_{2} \mathrm{NPs}_{\text {sere amended }}$ into the media to obtain a final concentration of 25,50 , and $100 \mu \mathrm{g} \mathrm{mL}^{-1}$. The media was poured into $9 \mathrm{~cm}$ diameter Petri dishes. After solidification, a $0.5 \mathrm{~cm}$ diameter disc of 5 days old $R$. solani culture was placed at the center of the dishes. The reduction percentage of pathogen growth was calculated using Equation $(3)[81,82]$ as follows:

Inhibition of pathogen growth $(\%)=\frac{\text { growth in the control }- \text { growth in the treatment }}{\text { growth in the control }} \times 100$

\subsubsection{Effect of $\mathrm{SiO}_{2}$ NPs on the Mycelium Fresh and Dry Weight of $R$. solani}

Mycelium dry weight was assessed according to the method described by Li et al. [83] with minor modifications. $50 \mathrm{~mL}$ of potato dextrose broth (PDB) medium was poured into a $250 \mathrm{~mL}$ Erlenmeyer flask. $\mathrm{SiO}_{2} \mathrm{NPs}$ were added to the media and the concentration was adjusted to 25,50 , and $100 \mu \mathrm{g} \mathrm{mL}^{-1}$. No $\mathrm{SiO}_{2} \mathrm{NPs}$ were added to the control; $0.5 \mathrm{~cm}$ diameter disc of 5 days old $R$. solani culture was placed gently on the surface of PDB media. The inoculated flasks were incubated at $28 \pm 2{ }^{\circ} \mathrm{C}$ for 5 days. For fresh weight assessment, the mycelium of $R$. solani from liquid media was harvested using a filtration-based method as previously described by Newell and Statzell-Tallman [84] with slight modifications. Briefly, the fungal mycelium was filtrated using a $40-\mu \mathrm{m}$-mesh nylon screen, washed with $25 \mathrm{~mL}$ distilled water, recollected on Whatman filter paper no. 1, then vacuumed for $30 \mathrm{~s}$ to abandon any free water from the samples. Subsequently, mycelia were kept in small Petri dishes to avoid rapid dehydration during fresh-weighting [84]. Fresh weight was assessed 
immediately after filtration. Samples were processed one by one through filtration and fresh-weighting. For dry weight assessment, the mycelia of $R$. solani left to dry at $50{ }^{\circ} \mathrm{C}$ for $24 \mathrm{~h}$ and reweighted. During the dry weight assay, fresh desiccant was maintained in the weighting chamber of the balance. The percentage of mycelium fresh and dry growth reduction was calculated according to Equation (4) as follows:

$$
\begin{aligned}
& \text { Inhibition of mycelium fresh/dry weight }(\%)= \\
& \frac{\text { Mycelium fresh/dry weight of control }- \text { Mycelium fresh/dry weight in the treatment }}{\text { Mycelium fresh/dry weight of control }} \times 100
\end{aligned}
$$

Five replicates were used for each concentration each replicate was represented with one flask. The experiment was repeated twice.

\subsubsection{Extracellular Conductivity}

Extracellular conductivity assay was carried out using a method described by Mahas and Kaur [85] with minor modifications. To obtain the fungal mycelium, $50 \mathrm{~mL}$ of nutrient broth (NB) was inoculated by a $6 \mathrm{~mm}$ mycelial disk of five days old $R$. solani culture. The inoculated NB was incubated for three days at $26^{\circ} \mathrm{C}$. Sterile distilled water was used to wash the collected mycelium. $100 \mathrm{mg}$ of collected mycelium was transferred into $50 \mathrm{~mL}$ PDB containing three concentrations of 25,50 , and $100 \mu \mathrm{g} \mathrm{mL}^{-1}$ of $\mathrm{SiO}_{2} \mathrm{NPs}$, and no particles were added to the control. The supernatants were collected at 0,12 , and $24 \mathrm{~h}$ of incubation by centrifuging the mycelial suspensions for $10 \mathrm{~min}$ at $10,000 \mathrm{rpm}$. The electrical conductivity of the supernatants was measured using a conductivity meter.

\subsection{Effect of $\mathrm{SiO}_{2} \mathrm{NPS}$ on Germination, Root and Shoot Length, and Vigor Indexes of R. solani-Infected Wheat Seedlings}

This experiment was conducted to study the effect of three $\mathrm{SiO}_{2} \mathrm{NPs}$ concentrations, 25,50 , and $100 \mu \mathrm{g} \mathrm{mL}^{-1}$, on the germination percentage, root length, shoot length, and vigor index of wheat cv. Misr-2 infected with $R$. solani. Inoculation with fungal isolate was the main plot, and $\mathrm{SiO}_{2} \mathrm{NPs}$ treatment was the subplot. Five replicates were used for each treatment; three wheat seeds were sown in each pot as one replicate. The seeds of wheat cultivar Misr-2 were soaked in three concentrations of $\mathrm{SiO}_{2} \mathrm{NPs}, 25,50$, and $100 \mu \mathrm{g} \mathrm{mL}^{-1}$ for $12 \mathrm{hr}$. The seeds were then divided into two groups; the first group was sown in 15 pots, which were previously inoculated with $R$. solani as described in the cultivar evaluation test. Five pots were used for each concentration of $\mathrm{SiO}_{2} \mathrm{NPs}$. The second group was sown in the same way except the soil was not inoculated with $R$. solani. Two controls were used in this experiment; Negative control (wheat seeds were soaked in water and sown in non-inoculated soil), Positive control (wheat seeds were soaked in water and sown in inoculated soil).

Two weeks after sowing dates, the wheat seedling was taken out of the pots and the roots were gently washed. The percentage of germinated seeds, roots, and shoots length, fresh and dry weight of wheat seedlings were measured. The germination percentage was calculated using Equation (5):

$$
\text { Germination }(\%)=\frac{\text { Number of germinated seeds }}{\text { Number of total seeds }} \times 100
$$

Moreover, the vigor index of wheat seedlings was calculated using two traits. Seedling vigor index based on the root and shoot length (SVIL) was measured according to Equation (6) as described by Abdul-Baki and Anderson [16] as follows:

$$
\text { SVIL }=(\text { shoot length }+ \text { root length }) \times \text { germination }(\%)
$$


Likewise, the seedling vigor index based on the weight was calculated using Equation (7) as follows:

$$
\text { SVIW }=\text { seedling dry mass at the end of the test } \times \text { germination }(\%)
$$

\subsection{Effect of $\mathrm{SiO}_{2}$ on Pre- and Post-Emergence Damping-Off and Root Rot of Wheat under} Inoculation with $R$. solani

Wheat cultivar Misr-2 was used for this test. Wheat seeds were treated with $\mathrm{SiO}_{2} \mathrm{NPs}$ at three concentrations, 25,50 , and $100 \mu \mathrm{g} \mathrm{mL}^{-1}$ for $12 \mathrm{~h}$. The treatments and experiment design were implemented as described in the above section. The inoculation was done as described in the cultivar evaluation test section. Pre-, post-emergence damping-off and root rot for wheat seedlings were evaluated two, four, and six weeks after the sowing date, respectively, as described previously.

\subsection{Stress-Associated Biochemical and Physiological Assessments}

The experiment was conducted and designed in the same way as described in the vigor index section. Leaves of three weeks old wheat seedlings from each treatment were used for the following measurements and five biological replicates were used for each trait.

\subsubsection{Pigments Content}

Chlorophyll a, b and carotenoids were measured in fresh leaves $(0.05 \mathrm{~g})$ suspended in $5 \mathrm{~mL}$ of ethyl alcohol (95\%) using equations recommended by Lichtenthaler [86].

\subsubsection{Reactive Oxygen Species}

Reactive oxygen species (ROS) were assessed by determination of superoxide anions $\mathrm{O}_{2}^{-\bullet}\left(\mu \mathrm{g} \mathrm{g}^{-1} \mathrm{FW}\right)$, hydrogen peroxide $\left(\mu \mathrm{mol} \mathrm{g}^{-1} \mathrm{FW}, \mathrm{H}_{2} \mathrm{O}_{2}\right)$, and hydroxyl radicals $(\bullet \mathrm{OH}$, $\mu \mathrm{mol} \mathrm{g}{ }^{-1} \mathrm{FW}$ ) via published methods of Yang et al. [87], Mukherjee and Choudhuri [88], and Halliwell et al. [89], respectively.

\subsubsection{Membrane Damage Criteria}

Lipid peroxidation was detected as described by Madhava Rao and Sresty [90] with some modifications. The thiobarbituric acid reaction was used to determine lipid peroxidation in wheat shoots by monitoring malondialdehyde formation as explained Methylglyoxal (MG) was estimated based on the method of Gilbert and Brandt [91].

\subsubsection{Resistance-Related Compounds and Enzymes}

Salicylic Acid (SA)

Fresh wheat leaves were used for the determination of SA as described by Warrier et al. [92]. Briefly, $100 \mathrm{mg}$ of leaf tissue were ground to a fine powder using liquid nitrogen, extracted with $1.0 \mathrm{~mL}$ of extraction solvent (chloroform, amyl alcohol, ether, and ethanol), then centrifuged at $10,000 \times g$ for $10 \mathrm{~min}$. subsequently, $100 \mu \mathrm{L}$ of the supernatant with up to $3 \mathrm{~mL}$ of freshly prepared ferric chloride $(0.1 \%)$ till the development of violet color. The absorbance of the complex was measured using spectrophotometry at $540 \mathrm{~nm}$ [92].

\section{Phenolic Compounds}

Phenolic compounds were determined using a Folin-Ciocalteu-based method as described by Kofalvi and Nassuth [93], using gallic acid as a standard curve. Total phenolics were expressed as $\mathrm{mg} \mathrm{g}^{-1} \mathrm{FW}$. Briefly, $300 \mathrm{mg}$ fresh leaf tissues were extracted in methanol $(50 \%)$ in a water bath $\left(70^{\circ} \mathrm{C}\right)$ for one hour. The methanolic extract was mixed with distilled water + Folin-Ciocalteu's reagent $+\mathrm{Na}_{2} \mathrm{CO}_{3}$ at room temperature. After $20 \mathrm{~min}$, the absorbance spectrum was measured at $725 \mathrm{~nm}$.

\section{Nitric Oxide Content (NO)}

Nitric oxide (NO) content was indirectly determined as described by Ding et al. [94] and modified by Hu et al. [95]. Briefly, $\mathrm{NO}$ was reacted with Greiss reagent (1\% sulfanil- 
amide/0.1\% N-(1-naphthyl)-ethylenediamine dihydrochloride in 5\% phosphate acid) was added for $30 \mathrm{~min}$ at room temperature till the appearance of azo violet color, which was measured spectrophotometrically at $550 \mathrm{~nm}$. $\mathrm{NaNO}_{2}$ was used to prepare the standard curve and the $\mathrm{NO}$ content was expressed as nmol g ${ }^{-1} \mathrm{FW}$.

Phenylalanine Ammonia-Lyase (PAL) and Polyphenol Oxidase (PPO) Activities

Phenylalanine ammonia-lyase (PAL; EC 4.3.1.5) and Polyphenol oxidase (PPO; EC 1.10.3.1) activities were examined using the protocol of Havir and Hanson [96] and Kumar and Khan [97], respectively.

\section{Flavonoids Content}

Total flavonoid content was colorimetrically assessed as described by Zou et al. [98] using aluminum chloride with slight modifications. Briefly, $100 \mathrm{mg}$ of leaf tissue was ground to a fine powder using liquid nitrogen, extracted with $1.0 \mathrm{~mL}$ methanol, then centrifuged at $10,000 \times g$ for $10 \mathrm{~min}$. Subsequently, about $0.5 \mathrm{~mL}$ of the supernatant was mixed with $2 \mathrm{~mL}$ of distilled water and $150 \mu \mathrm{L}$ of $5 \%$ sodium nitrate and incubated for $6 \mathrm{~min}$. After incubation, $150 \mu \mathrm{L}$ of aluminum chloride $(10 \%)$ and $2 \mathrm{~mL}$ of sodium hydroxide (1 M) were added and re-incubated at room temperature for $15 \mathrm{~min}$. The absorbance of the mixtures was measured at $510 \mathrm{~nm}$.

\subsubsection{Non-Enzymatic and Enzymatic Antioxidants}

Non-enzymatic molecules in terms of reduced glutathione (GSH) and ascorbic acid (ASA) were studied based on the methods of Ellman [99] and Jagota and Dani [100]. The antioxidative enzymes of shoots were monitored by screening the specific activities of catalase (CAT, $\mathrm{U} \mathrm{mg}^{-1}$ protein $\mathrm{g}^{-1} \mathrm{FW} \mathrm{min}^{-1}$ ), superoxide dismutase (SOD, $\mathrm{U} \mathrm{mg}^{-1}$

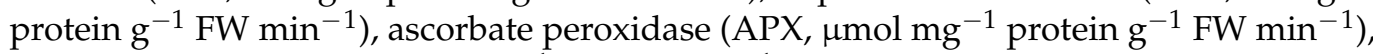
guaiacol peroxidase (POD, $\left(\mathrm{U} \mathrm{mg}^{-1}\right.$ protein $\left.\mathrm{min}^{-1}\right)$ using the recommended procedures of Noctor et al. [101], Misra and Fridovich [102], Silva et al. [103] and Zaharieva et al. [104], respectively.

\subsection{Statistical Analysis}

Throughout this study, all experiments were laid out using a full factorial split-plot design arranged in completely randomized blocks using $R$. solani-infection (healthy vs. infected) as main plots and $\mathrm{SiO}_{2}$ treatments $\left(0,25,50\right.$, and $\left.100 \mu \mathrm{g} \mathrm{mL}^{-1} \mathrm{SiO}_{2}\right)$ in the subplots. All experiments were carried out using at least three biological replicates for each treatment. The analysis of variance (ANOVA) was used to test the significant differences among different infection levels $\left(p_{\text {infection }}\right)$, treatments $\left(p_{\text {treatment }}\right)$, and their interaction $\left(p_{\text {infection }} \times\right.$ treatment $)$. Tukey's honestly significant difference (HSD) test was used for posthoc analysis $\left(p_{\text {infection } \times \text { treatment }}<0.05\right)$. The data were analyzed using JMP data analysis software version 14 .

\section{Conclusions}

In conclusion, $\mathrm{SiO}_{2} \mathrm{NPs}$ treatment reduced the infection rate and suppressed the growth of $R$. solani on wheat. Our findings demonstrated that $\mathrm{SiO}_{2} \mathrm{NPs}$ mitigate the negative effect of $R$. solani on wheat seedlings via the simultaneous activation of a multilayered defense system that involves at least three key mechanisms. (i) $\mathrm{SiO}_{2} \mathrm{NPs}$ have a direct dose-dependent fungistatic activity against the vegetative growth of $R$. solani. (ii) $\mathrm{SiO}_{2}$ NPs induced the accumulation of defense-related compounds, particularly SA and its major biosynthetic enzyme PAL, and (iii) $\mathrm{SiO}_{2}$ NPs induce the activation of both enzymatic (POD, SOD, APX, CAT, and PPO) and non-enzymatic (phenolics and flavonoids) antioxidant defense machinery to neutralize the destructive effect of ROS, lipid peroxidation, and methylglyoxal to maintain their homeostasis within $R$. solani-infected plants. Collectively, it is plausible to propose that the application of $\mathrm{SiO}_{2} \mathrm{NPs}$ could be considered as 
an alternative/eco-friendly approach to protect wheat plants from root rot-causing phytopathogenic fungi due to their suppressive role against the infection caused by $R$. solani.

Supplementary Materials: The following are available online at https:/ / www.mdpi.com/article/10 .3390/plants10122758/s1, Figure S1: Energy-dispersive X-ray spectroscopy (EDS) elemental mapping of Si K $\alpha 1$ (A) and $\mathrm{O} K \alpha 1$ (B).

Author Contributions: Conceptualization, A.S.A., Y.N. and M.F.A.D.; methodology, A.S.A., R.M.E.A. and M.F.A.D.; software, A.S.A., Y.S.A.M., Y.N. and O.O.A.; validation, A.S.A., R.M.E.-A. and M.F.A.D.; formal analysis, A.S.A. and Y.N.; investigation, A.S.A., R.M.E.-A. and M.F.A.D.; resources, A.S.A. and Y.S.A.M.; data curation, A.S.A., M.F.A.D. and Y.N.; writing-original draft preparation, A.S.A., Y.S.A.M., Y.N., O.O.A., R.M.E.-A. and M.F.A.D.; writing-review and editing, A.S.A. and Y.N.; visualization, Y.N.; supervision, A.S.A., Y.S.A.M., Y.N. and O.O.A.; project administration, A.S.A. and M.F.A.D.; funding acquisition, A.S.A. and Y.S.A.M. All authors have read and agreed to the published version of the manuscript.

Funding: The APC was funded by the Deanship of Scientific Research at King Khalid University, KSA, grant number (RGP 2/165/42).

Institutional Review Board Statement: Not applicable.

Informed Consent Statement: Not applicable.

Data Availability Statement: The data that supports the findings of this study are contained within the article or Supplementary Materials and available from the corresponding author upon reasonable request.

Acknowledgments: The authors highly acknowledge the Deanship of Scientific Research at King Khalid University for funding this work through the Program of Research Groups under grant number (RGP 2/165/42). Y.N. and Y.S.A.M. would like to extend their appreciation to the Graduate Student \& Research Affairs Sector of Tanta University, Egypt. We also thank all staff members of our laboratories for their helpful discussions and comments.

Conflicts of Interest: The authors declare that there is no conflict of interest, and they have no known competing financial interests or personal relationships that could have appeared to influence the work reported in this paper.

\section{References}

1. FAOSTAT Food and Agriculture Organization of the United Nations. Available online: http://www.fao.org/faostat/en/\#data/ QC (accessed on 13 February 2020).

2. González García, V.; Portal Onco, M.A.; Rubio Susan, V. Review. Biology and systematics of the form genus Rhizoctonia. Span. J. Agric. Res. 2006, 4, 55-79. [CrossRef]

3. Hamada, M.; Yin, Y.; Chen, H.; Ma, Z. The escalating threat of Rhizoctonia cerealis, the causal agent of sharp eyespot in wheat. Pest Manag. Sci. 2011, 67, 1411-1419. [CrossRef] [PubMed]

4. Sneh, B.; Burpee, L.; Ogoshi, A. Identification of Rhizoctonia Species; Aps Press: St. Paul, MI, USA, 1991.

5. Carling, D.E.; Kuninaga, S. DNA base sequence homology in Rhizoctonia solani Kühn: Inter- and intragroup relatedness of anastomosis group-9. Phytopathology 1990, 80, 1362. [CrossRef]

6. Ogoshi, A.; Cook, R.J.; Bassett, E.N. Rhizoctonia species and anastomosis groups causing root rot of wheat and barley in the Pacific Northwest. Phytopathology 1990, 80. [CrossRef]

7. Weller, J.L.; Terry, M.J.; Rameau, C.; Reid, J.B.; Kendrick, R.E. The phytochrome-deficient pcd1 mutant of pea is unable to convert heme to biliverdin IX[alpha]. Plant Cell 1996, 8, 55-67. [CrossRef] [PubMed]

8. Pumphrey, F.V. Influence of tillage and nitrogen fertilizer on Rhizoctonia root rot (bare patch) of winter wheat. Plant Dis. 1987, 71, 125. [CrossRef]

9. Smiley, R.W. Impact of fungicide seed treatments on Rhizoctonia root rot, take-all, eyespot, and growth of winter wheat. Plant Dis. 1990, 74, 782. [CrossRef]

10. Shu, C.; Sun, S.; Chen, J.; Chen, J.; Zhou, E. Comparison of different methods for total RNA extraction from sclerotia of Rhizoctonia solani. Electron. J. Biotechnol. 2014, 17, 50-54. [CrossRef]

11. James Cook, R. Wheat root health management and environmental concern. Can. J. Plant Pathol. 1992, 14. [CrossRef]

12. Ray, R.V.; Jenkinson, P.; Edwards, S.G. Effects of fungicides on eyespot, caused predominantly by Oculimacula acuformis, and yield of early-drilled winter wheat. Crop. Prot. 2004, 23, 1199-1207. [CrossRef]

13. Kataria, H.R.; Hugelshofer, U.; Gisi, U. Sensitivity of Rhizoctonia species to different fungicides. Plant Pathol. 1991, 40, $203-211$. [CrossRef] 
14. Nel, A.; Xia, T.; Mädler, L.; Li, N. Toxic potential of materials at the nanolevel. Science 2006, 311, 622-627. [CrossRef] [PubMed]

15. Bonner, F.T. Germination response of loblolly Pine to temperature differentials on two-way thermogradient plante. J. Seed Technol. 1983, 8, 6-14.

16. Abdul-Baki, A.A.; Anderson, J.D. Vigor determination in soybean seed by multiple criteria1. Crop Sci. 1973, 13, 630-633. [CrossRef]

17. Siddiqui, M.H.; Al-Whaibi, M.H. Role of nano-SiO2 in germination of tomato (Lycopersicum esculentum seeds Mill.). Saudi J. Biol. Sci. 2014, 21, 13-17. [CrossRef] [PubMed]

18. Sabaghnia, N.; Janmohammadi, M. Graphic analysis of nano-silicon by salinity stress interaction on germination properties of lentil using the biplot method. Agric. For. 2014, 60, 24-40.

19. Sabaghnia, N.; Janmohammadi, M. Effect of nano-silicon particles application on salinity tolerance in early growth of some lentil genotypes/Wpływ nanoczastek krzemionki na tolerancję zasolenia we wczesnym rozwoju niektórych genotypów soczewicy. Ann. UMCS Biol. 2015, 69. [CrossRef]

20. Rawat, P.S.; Kumar, R.; Ram, P.; Pandey, P. Effect of nanoparticles on wheat seed germination and seedling growth. Int. J. Agric. Biosyst. Eng. 2018, 12, 13-16.

21. Li, R.; He, J.; Xie, H.; Wang, W.; Bose, S.K.; Sun, Y.; Hu, J.; Yin, H. Effects of chitosan nanoparticles on seed germination and seedling growth of wheat (Triticum aestivum L.). Int. J. Biol. Macromol. 2019, 126, 91-100. [CrossRef]

22. Liang, Y.; Sun, W.; YG, Z.; Christie, P. Mechanisms of silicon-mediated alleviation of abiotic stresses in higher plants: A review. Environ. Pollut. 2007, 147, 422-428. [CrossRef] [PubMed]

23. De Curtis, F.; De Cicco, V.; Lima, G. Efficacy of biocontrol yeasts combined with calcium silicate or sulphur for controlling durum wheat powdery mildew and increasing grain yield components. Field Crop Res. 2012, 134. [CrossRef]

24. Filho, J.A.W.; Duarte, H.S.S.; Rodrigues, F.A. Effect of foliar application of potassium silicate and fungicide on the severity of leaf rust and yellow leaf spot in wheat. Rev. Ceres 2013, 60, 726-730. [CrossRef]

25. Rodrigues, F.A.; Dallagnol, L.J.; Duarte, H.S.S.; Datnoff, L.E. Silicon control of foliar diseases in monocots and dicots. In Silicon and Plant Diseases; Springer International Publishing: Cham, Switzerland, 2015.

26. Côté-Beaulieu, C.; Chain, F.; Menzies, J.G.; Kinrade, S.D.; Bélanger, R.R. Absorption of aqueous inorganic and organic silicon compounds by wheat and their effect on growth and powdery mildew control. Environ. Exp. Bot. 2009, 65, 155-161. [CrossRef]

27. Rodgers-Gray, B.S.; Shaw, M.W. Substantial reductions in winter wheat diseases caused by addition of straw but not manure to soil. Plant Pathol. 2000, 49, 590-599. [CrossRef]

28. Pagani, A.P.S.; Dianese, A.C.; Café-Filho, A.C. Management of wheat blast with synthetic fungicides, partial resistance and silicate and phosphite minerals. Phytoparasit 2014, 42, 609-617. [CrossRef]

29. Rodgers-Gray, B.S.; Shaw, M.W. Effects of straw and silicon soil amendments on some foliar and stem-base diseases in pot-grown winter wheat. Plant Pathol. 2004, 53. [CrossRef]

30. Domiciano, G.P.; Rodrigues, F.A.; Guerra, A.M.N.; Vale, F.X.R. Infection process of Bipolaris sorokiniana on wheat leaves is affected by silicon. Trop. Plant Pathol. 2013, 38, 258-263. [CrossRef]

31. Azizian-Shermeh, O.; Valizadeh, M.; Taherizadeh, M.; Beigomi, M. Phytochemical investigation and phytosynthesis of eco-friendly stable bioactive gold and silver nanoparticles using petal extract of saffron (Crocus sativus L.) and study of their antimicrobial activities. Appl. Nanosci. 2020, 10, 2907-2920. [CrossRef]

32. Alhumaydhi, F.A.; Khan, I.; Rauf, A.; Qureshi, M.N.; Aljohani, A.S.M.; Khan, S.A.; Khalil, A.A.; El-Esawi, M.A.; Muhammad, N. Synthesis, characterization, biological activities, and catalytic applications of alcoholic extract of saffron (Crocus sativus) flower stigma-based gold nanoparticles. Green Process. Synth. 2021, 10, 230-245. [CrossRef]

33. Tripathi, D.K.; Singh, S.; Singh, V.P.; Prasad, S.M.; Dubey, N.K.; Chauhan, D.K. Silicon nanoparticles more effectively alleviated UV-B stress than silicon in wheat (Triticum aestivum) seedlings. Plant Physiol. Biochem. 2017, 110, 70-81. [CrossRef]

34. Shokri, B.; Firouzjah, M.A.; Hosseini, S.I. FTIR analysis of silicon dioxide thin film deposited by metal organic-based PECVD. In Proceedings of the 19th International Plasma Chemistry Symposium, Bochum, Germany, 27-31 July 2009; pp. 1-4. Available online: www.ispc-conference.org (accessed on 10 December 2021).

35. Verma, J.; Bhattacharya, A. analysis on synthesis of silica nanoparticles and its effect on growth of T. harzianum \& Rhizoctonia species. Biomed. J. Sci. Tech. Res. 2018, 10. [CrossRef]

36. Saravanan, S.; Dubey, R.S. Synthesis of $\mathrm{SiO}_{2}$ nanoparticles by sol-gel method and their optical and structural properties. Rom. J. Inf. Sci. Technol. 2020, 23, 105-112.

37. Aziz, R.A.; Sopyan, I. Synthesis of $\mathrm{TiO}_{2}-\mathrm{SiO}_{2}$ powder and thin film photocatalysts by sol-gel method. Indian J. Chem. 2009, 48, 951-957.

38. Arun Kumar, D.; Merline Shyla, J.; Xavier, F.P. Synthesis and characterization of TiO2/SiO2 nano composites for solar cell applications. Appl. Nanosci. 2012, 2, 429-436. [CrossRef]

39. Sooksaen, P.; Suttiruengwong, S.; Oniem, K.; Ngamlamiad, K.; Atireklapwarodom, J. Fabrication of porous bioactive glassceramics via decomposition of natural fibres. J. Met. Mater. Miner. 2017, 18, 85-91.

40. Derbalah, A.; Shenashen, M.; Hamza, A.; Mohamed, A.; El Safty, S. Antifungal activity of fabricated mesoporous silica nanoparticles against early blight of tomato. Egypt. J. Basic Appl. Sci. 2018, 5, 145-150. [CrossRef]

41. Salem, H.F.; Eid, K.A.M.; Sharaf, M.A. Formulation and evaluation of silver nanoparticles as antibacterial and antifungal agents with a minimal cytotoxic effect. Int. J. Drug Deliv. 2011, 3, 293-304. 
42. Capeletti, L.B.; de Oliveira, L.F.; Gonçalves, K.d.A.; de Oliveira, J.F.A.; Saito, Â.; Kobarg, J.; dos Santos, J.H.Z.; Cardoso, M.B. Tailored silica-antibiotic nanoparticles: Overcoming bacterial resistance with low cytotoxicity. Langmuir 2014, 30, 7456-7464. [CrossRef]

43. Wang, M.; Gao, L.; Dong, S.; Sun, Y.; Shen, Q.; Guo, S. Role of silicon on plant-pathogen interactions. Front. Plant Sci. 2017, 8, 701. [CrossRef]

44. Debona, D.; Rodrigues, F.A.; Datnoff, L.E. Silicon's role in abiotic and biotic plant stresses. Annu. Rev. Phytopathol. 2017, 55, 85-107. [CrossRef]

45. Weinhold, A.R.; Sinclair, J.B. Rhizoctonia solani: Penetration, colonization, and host response. Rhizoctonia Species Taxon. Mol. Biol. Ecol. Pathol. Dis. Control 1996, 163-174. [CrossRef]

46. Ahammed, G.J.; Yang, Y. Mechanisms of silicon-induced fungal disease resistance in plants. Plant Physiol. Biochem. 2021, 165, 200-206. [CrossRef] [PubMed]

47. Dorneles, K.R.; Dallagnol, L.J.; Pazdiora, P.C.; Rodrigues, F.A.; Deuner, S. Silicon potentiates biochemical defense responses of wheat against tan spot. Physiol. Mol. Plant Pathol. 2017, 97, 69-78. [CrossRef]

48. Elsherbiny, E.A.; Taher, M.A. Silicon induces resistance to postharvest rot of carrot caused by Sclerotinia sclerotiorum and the possible of defense mechanisms. Postharvest Biol. Technol. 2018, 140, 11-17. [CrossRef]

49. Ahanger, M.A.; Bhat, J.A.; Siddiqui, M.H.; Rinklebe, J.; Ahmad, P. Integration of silicon and secondary metabolites in plants: A significant association in stress tolerance. J. Exp. Bot. 2020, 71, 6758-6774. [CrossRef]

50. Dawood, M.F.A.; Tahjib-Ul-arif, M.; Al Mamun Sohag, A.; Abdel Latef, A.A.H.; Ragaey, M.M. Mechanistic insight of allantoin in protecting tomato plants against ultraviolet c stress. Plants 2021, 10, 11. [CrossRef]

51. Hoque, T.S.; Hossain, M.A.; Mostofa, M.G.; Burritt, D.J.; Fujita, M.; Tran, L.-S.P. Methylglyoxal: An Emerging Signaling Molecule in Plant Abiotic Stress Responses and Tolerance. Front. Plant Sci. 2016, 7. [CrossRef]

52. Herrera-Vásquez, A.; Salinas, P.; Holuigue, L. Salicylic acid and reactive oxygen species interplay in the transcriptional control of defense genes expression. Front. Plant Sci. 2015, 6, 1-9. [CrossRef]

53. Abdelrhim, A.S.; Dawood, M.F.A.; Galal, A.A. Hydrogen peroxide-mixed compounds and/or microwave radiation as alternative control means against onion seed associated pathogens, Aspergillus niger and Fusarium oxysporum. J. Plant Pathol. 2021, 1, 1-15. [CrossRef]

54. Ahanger, M.A.; Agarwal, R.M.; Tomar, N.S.; Shrivastava, M. Potassium induces positive changes in nitrogen metabolism and antioxidant system of oat (Avena sativa L cultivar Kent). J. Plant Interact. 2015, 10, 211-223. [CrossRef]

55. Bagy, H.M.M.K.; Hassan, E.A.; Nafady, N.A.; Dawood, M.F.A. Efficacy of arbuscular mycorrhizal fungi and endophytic strain Epicoccum nigrum ASU11 as biocontrol agents against blackleg disease of potato caused by bacterial strain Pectobacterium carotovora subsp. atrosepticum PHY7. Biol. Control 2019, 134, 103-113. [CrossRef]

56. Rodrigues, F.Á.; Benhamou, N.; Datnoff, L.E.; Jones, J.B.; Bélanger, R.R. Ultrastructural and cytochemical aspects of siliconmediated rice blast resistance. Phytopathology 2003, 93. [CrossRef]

57. Suriyaprabha, R.; Karunakaran, G.; Kavitha, K.; Yuvakkumar, R.; Rajendran, V.; Kannan, N. Application of silica nanoparticles in maize to enhance fungal resistance. IET Nanobiotechnol. 2014, 8, 133-137. [CrossRef] [PubMed]

58. Bari, R.; Jones, J.D.G. Role of plant hormones in plant defence responses. Plant Mol. Biol. 2009, 69, 473-488. [CrossRef] [PubMed]

59. Nehela, Y.; Hijaz, F.; Elzaawely, A.A.; El-Zahaby, H.M.; Killiny, N. Citrus phytohormonal response to Candidatus Liberibacter asiaticus and its vector Diaphorina citri. Physiol. Mol. Plant Pathol. 2018, 102, 24-35. [CrossRef]

60. Nehela, Y.; Killiny, N. Multiple phytohormonal signaling mediates citrus response to the bacterial pathogen Candidatus Liberibacter asiaticus. Phytopathology 2018, 108, 10.

61. Nehela, Y.; Killiny, N. Melatonin is involved in citrus response to the pathogen huanglongbing via modulation of phytohormonal biosynthesis. Plant Physiol. 2020, 184, 2216-2239. [CrossRef]

62. Dawood, M.F.A.; Azooz, M.M. Insights into the oxidative status and antioxidative responses of germinating broccoli (Brassica oleracea var. italica L.) seeds in tungstate contaminated water. Chemosphere 2020, 261, 127585. [CrossRef] [PubMed]

63. Bittner, N.; Trauer-Kizilelma, U.; Hilker, M. Early plant defence against insect attack: Involvement of reactive oxygen species in plant responses to insect egg deposition. Planta 2017, 245, 993-1007. [CrossRef] [PubMed]

64. Fleck, A.T.; Nye, T.; Repenning, C.; Stahl, F.; Zahn, M.; Schenk, M.K. Silicon enhances suberization and lignification in roots of rice (Oryza sativa). J. Exp. Bot. 2011, 62, 2001. [CrossRef] [PubMed]

65. Asgari, F.; Majd, A.; Jonoubi, P.; Najafi, F. Effects of silicon nanoparticles on molecular, chemical, structural and ultrastructural characteristics of oat (Avena sativa L.). Plant Physiol. Biochem. PPB 2018, 127, 152-160. [CrossRef] [PubMed]

66. Cai, K.; Gao, D.; Luo, S.; Zeng, R.; Yang, J.; Zhu, X. Physiological and cytological mechanisms of silicon-induced resistance in rice against blast disease. Physiol. Plant. 2008, 134, 324-333. [CrossRef] [PubMed]

67. Liang, Y.; Si, J.; Römheld, V. Silicon uptake and transport is an active process in Cucumis sativus. New Phytol. 2005, 167, 797-804. [CrossRef] [PubMed]

68. Sallam, N.M.A.; AbdElfatah, H.A.S.; Dawood, M.F.A.; Hassan, E.A.; Mohamed, M.S.; Khalil Bagy, H.M.M. Physiological and histopathological assessments of the susceptibility of different tomato (Solanum lycopersicum) cultivars to early blight disease. Eur. J. Plant Pathol. 2021, 160, 541-556. [CrossRef]

69. Constabel, C.P.; Barbehenn, R. Defensive roles of polyphenol oxidase in plants. Induc. Plant Resist. Herbiv. 2008, 253-270. [CrossRef] 
70. Nagaonkar, D.; Gaikwad, S.; Rai, M. Catharanthus roseus leaf extract-synthesized chitosan nanoparticles for controlled in vitro release of chloramphenicol and ketoconazole. Colloid Polym. Sci. 2015, 293, 1465-1473. [CrossRef]

71. Hossain, A.; Abdallah, Y.; Ali, M.A.; Masum, M.M.I.; Li, B.; Sun, G.; Meng, Y.; Wang, Y.; An, Q. Lemon-fruit-based green synthesis of zinc oxide nanoparticles and titanium dioxide nanoparticles against soft rot bacterial pathogen Dickeya dadantii. Biomolecules 2019, 9, 863. [CrossRef] [PubMed]

72. Masum, M.I.; Siddiqa, M.M.; Ali, K.A.; Zhang, Y.; Abdallah, Y.; Ibrahim, E.; Qiu, W.; Yan, C.; Li, B. Biogenic synthesis of silver nanoparticles using Phyllanthus emblica fruit extract and its inhibitory action against the pathogen Acidovorax oryzae strain RS-2 of rice bacterial brown stripe. Front. Microbiol. 2019, 10. [CrossRef]

73. Ogunyemi, S.O.; Abdallah, Y.; Zhang, M.; Fouad, H.; Hong, X.; Ibrahim, E.; Masum, M.M.I.; Hossain, A.; Mo, J.; Li, B. Green synthesis of zinc oxide nanoparticles using different plant extracts and their antibacterial activity against Xanthomonas oryzae pv. oryzae. Artif. Cells Nanomed. Biotechnol. 2019, 47, 341-352. [CrossRef] [PubMed]

74. Alejandre, A.; Medina, F.; Salagre, P.; Fabregat, A.; Sueiras, J.E. Characterization and activity of copper and nickel catalysts for the oxidation of phenol aqueous solutions. Appl. Catal. B Environ. 1998, 18, 307-315. [CrossRef]

75. Atallah, O.O.; Osman, A.; Ali, M.A.S.; Sitohy, M. Soybean $\beta$-conglycinin and catfish cutaneous mucous p22 glycoproteins deteriorate sporangial cell walls of Pseudoperonospora cubensis and suppress cucumber downy mildew. Pest Manag. Sci. 2021, 77, 3313-3324. [CrossRef] [PubMed]

76. Atallah, O.; Yassin, S. Aspergillus spp. eliminate Sclerotinia sclerotiorum by imbalancing the ambient oxalic acid concentration and parasitizing its sclerotia. Environ. Microbiol. 2020, 22, 5265-5279. [CrossRef] [PubMed]

77. Botha, A.; Denman, S.; Lamprecht, S.C.; Mazzola, M.; Crous, P.W. Characterisation and pathogenicity of Rhizoctonia isolates associated with black root rot of strawberries in the Western Cape Province, South Africa. Australas. Plant Pathol. 2003, 32, 195-201. [CrossRef]

78. Raju, K.; MK, N. Survey and assessment for the post-harvest diseases of onion in North-Eastern Karnataka. Karnataka J. Agric. Sci. 2007, 20, 164-165.

79. Beale, R.; Phillion, D.; Headrick, J.; O'reilly, P.; Cox, J. MON65500: A unique fungicide for the control of take-all in wheat. In Proceedings of the 1998 Brighton Conference, Farnham, UK.-Pests and Diseases, Brighton, UK, 16-19 November 1998; Farnham Survey, British Crop Protection Council: Farnham, UK, 1998; pp. 343-350.

80. Joshi, S.M.; De Britto, S.; Jogaiah, S.; Ito, S. Mycogenic selenium nanoparticles as potential new generation broad spectrum antifungal molecules. Biomolecules 2019, 9, 419. [CrossRef] [PubMed]

81. EL-Nagar, A.; Elzaawely, A.A.; Taha, N.A.; Nehela, Y. The antifungal activity of gallic acid and its derivatives against Alternaria solani, the causal agent of tomato early blight. Agronomy 2020, 10, 1402. [CrossRef]

82. Nehela, Y.; Taha, N.A.; Elzaawely, A.A.; Xuan, T.D.; Amin, M.A.; Ahmed, M.E.; El-Nagar, A. Benzoic acid and its hydroxylated derivatives suppress early blight of tomato (Alternaria solani) via the induction of salicylic acid biosynthesis and enzymatic and nonenzymatic antioxidant defense machinery. J. Fungi 2021, 7, 663. [CrossRef]

83. Li, Q.; Jiang, Y.; Ning, P.; Zheng, L.; Huang, J.; Li, G.; Jiang, D.; Hsiang, T. Suppression of Magnaporthe oryzae by culture filtrates of Streptomyces globisporus JK-1. Biol. Control 2011, 58, 139-148. [CrossRef]

84. Newell, S.Y.; Statzell-Tallman, A. Factors for conversion of fungal biovolume values to biomass, carbon and nitrogen: Variation with mycelial ages, growth conditions, and strains of fungi from a salt marsh. Oikos 1982, 39, 261. [CrossRef]

85. Manhas, R.K.; Kaur, T. Biocontrol potential of Streptomyces hydrogenans strain DH16 toward Alternaria brassicicola to control damping off and black leaf spot of Raphanus sativus. Front. Plant Sci. 2016, 7, 1869. [CrossRef] [PubMed]

86. Lichtenthaler, H.K. Chlorophylls and carotenoids: Pigments of photosynthetic biomembranes. Methods Enzymol. 1987, 148, 350-382. [CrossRef]

87. Yang, H.; Wu, F.; Cheng, J. Reduced chilling injury in cucumber by nitric oxide and the antioxidant response. Food Chem. 2011, 127, 1237-1242. [CrossRef] [PubMed]

88. Mukherjee, S.P.; Choudhuri, M.A. Implications of water stress-induced changes in the levels of endogenous ascorbic acid and hydrogen peroxide in Vigna seedlings. Physiol. Plant. 1983, 58, 166-170. [CrossRef]

89. Halliwell, B.; Gutteridge, J.M.C.; Aruoma, O.I. The deoxyribose method: A simple "test-tube" assay for determination of rate constants for reactions of hydroxyl radicals. Anal. Biochem. 1987, 165, 215-219. [CrossRef]

90. Madhava Rao, K.V.; Sresty, T.V.S. Antioxidative parameters in the seedlings of pigeonpea (Cajanus cajan (L.) Millspaugh) in response to Zn and Ni stresses. Plant Sci. 2000, 157, 113-128. [CrossRef]

91. Gilbert, R.P.; Brandt, R.B. Spectrophotometric determination of methyl glyoxal with 2,4-dinitrophenylhydrazine. Anal. Chem. 2002, 47, 2418-2422. [CrossRef] [PubMed]

92. Warrier, R.R.; Paul, M.; Plant, M.V.V.-G. Estimation of salicylic acid in Eucalyptus leaves using spectrophotometric methods. Genet. Plant Physiol. 2013, 3, 90-97.

93. Kofalvi, S.A.; Nassuth, A. Influence of wheat streak mosaic virus infection on phenylpropanoid metabolism and the accumulation of phenolics and lignin in wheat. Physiol. Mol. Plant Pathol. 1995, 47, 365-377. [CrossRef]

94. Ding, A.H.; Nathan, C.F.; Stuehr, D.J. Release of reactive nitrogen intermediates and reactive oxygen intermediates from mouse peritoneal macrophages. Comparison of activating cytokines and evidence for independent production. J Immunol. 1988, 141, 2407-2412. 
95. Hu, X.; Neill, S.J.; Cai, W.; Tang, Z. NO-mediated hypersensitive responses of rice suspension cultures induced by incompatible elicitor. Chin. Sci. Bull. 2003, 48, 358-363. [CrossRef]

96. Havir, E.A.; Hanson, K.R. L-Phenylalanine ammonia-lyase (maize and potato). Evidence that the enzyme is composed of four subunits. Biochemistry 2002, 12, 1583-1591. [CrossRef]

97. Kumar, K.B.; Khan, P.A. Peroxidase and polyphenol oxidase in excised ragi (Eleusine corocana cv PR 202) leaves during senescence. Indian J. Exp. Biol. 1982, 412-416.

98. Zou, Y.; Lu, Y.; Wei, D. Antioxidant activity of a flavonoid-rich extract of Hypericum perforatum L. in vitro. J. Agric. Food Chem. 2004, 52, 5032-5039. [CrossRef]

99. Ellman, G.L. Tissue sulfhydryl groups. Arch. Biochem. Biophys. 1959, 82, 70-77. [CrossRef]

100. Jagota, S.K.; Dani, H.M. A new colorimetric technique for the estimation of vitamin C using Folin phenol reagent. Anal. Biochem. 1982, 127. [CrossRef]

101. Noctor, G.; Mhamdi, A.; Foyer, C.H. Oxidative stress and antioxidative systems: Recipes for successful data collection and interpretation. Plant. Cell Environ. 2016, 39. [CrossRef]

102. Misra, H.P.; Fridovich, I. The role of superoxide anion in the autoxidation of epinephrine and a simple assay for superoxide dismutase. J. Biol. Chem. 1972, 247, 3170-3175. [CrossRef]

103. Silva, E.N.; Silveira, J.A.G.; Aragão, R.M.; Vieira, C.F.; Carvalho, F.E.L. Photosynthesis impairment and oxidative stress in Jatropha curcas exposed to drought are partially dependent on decreased catalase activity. Acta Physiol. Plant. 2018, 41, 1-12. [CrossRef]

104. Zaharieva, T.; Yamashita, K.; Matsumoto, H. Iron deficiency induced changes in ascorbate content and enzyme activities related to ascorbate metabolism in cucumber roots. Plant Cell Physiol. 1999, 40, 273-280. [CrossRef] 